\title{
Natural history and molecular evolution of demersal Mediterranean sharks and skates inferred by comparative phylogeographic and demographic analyses
}

\author{
Alice Ferrari ${ }^{1}$, Fausto Tinti ${ }^{\text {Corresp.., }}{ }^{1}$, Victoria Bertucci Maresca ${ }^{1,2}$, Alessandro Velonà ${ }^{1}$, Rita Cannas ${ }^{3}$, \\ Ioannis Thasitis ${ }^{4}$, Filipe Oliveira Costa ${ }^{5}$, Maria Cristina Follesa ${ }^{3}$, Daniel Golani ${ }^{6}$, Farid Hemida ${ }^{7}$, Sarah J \\ Helyar $^{8}{ }^{\text {, }}$ Cecilia Mancusi ${ }^{9}$, Antonello Mulas ${ }^{3}$, Fabrizio Serena ${ }^{10}$, Letizia Sion ${ }^{11}$, Marco Stagioni ${ }^{1}$, Alessia \\ Cariani $^{1}$ \\ 1 Department of Biological, Geological \& Environmental Sciences (BiGeA), University of Bologna, Bologna, Italy \\ 2 Department of Life Sciences, University of Trieste, Trieste, Italy \\ 3 Department of Life Sciences and Environment, University of Cagliari, Cagliari, Italy \\ 4 Department of Fisheries and Marine Research, Ministry of Agriculture, Natural Resources and Environment, Nicosia, Cyprus \\ 5 Centre of Molecular and Environmental Biology (CBMA), University of Minho, Braga, Portugal \\ 6 Department of Evolution, Systematics and Ecology, Hebrew University of Jerusalem, Jerusalem, Israel \\ 7 Ecole Nationale Supérieure des Sciences de la Mer et de Aménagement du Littoral (ENSSMAL), Algiers, Algeria \\ 8 School of Biological Sciences, Institute for Global Food Security, The Queen's University Belfast, Belfast, United Kingdom \\ 9 Regional Agency for Environmental Protection-Toscana (ARPAT), Livorno, Italy \\ 10 Institute Coastal Marine Environment, Italian National Research Council (CNR -IAMC), Mazara del Vallo, Italy \\ 11 Department of Biology, University of Bari, Bari, Italy \\ Corresponding Author: Fausto Tinti \\ Email address: fausto.tinti@unibo.it
}

Background. The unique and complex paleoclimatic and paleogeographic events which affected the Mediterranean Sea since late Miocene deeply influenced the distribution and evolution of marine organisms and shaped their genetic structure. Following the Messinian salinity crisis and the sea-level fluctuations during the Pleistocene, several Mediterranean marine species developed deep genetic differentiation, and some underwent rapid radiation. Here, we consider two of the most prioritized groups for conservation in the light of their evolutionary history: sharks and rays (elasmobranchs). This paper deals with a comparative multispecies analysis of phylogeographic structure and historical demography in two pairs of sympatric, phylogenetically- and ecologically-related elasmobranchs, two scyliorhinid catsharks (Galeus melastomus, Scyliorhinus canicula) and two rajid skates (Raja clavata, Raja miraletus). Sampling and experimental analyses were designed to primarily test if the Sicilian Channel can be considered as effective eco-physiological barrier for Mediterranean demersal sympatric elasmobranchs.

Methods. The phylogeography and the historical demography of target species were inferred by analysing the nucleotide variation of three mitochondrial DNA markers (i.e. partial sequence of COI, NADH2 and CR) obtained from a total of 248 individuals sampled in the Western and Eastern Mediterranean Sea as well as in the adjacent northeastern Atlantic Ocean. Phylogeographic analysis was performed by haplotype networking and testing spatial genetic differentiation of samples (i.e. analysis of molecular variance and of principal components). Demographic history of Mediterranean populations was reconstructed using mismatch distribution and Bayesian Skyline Plot analyses.

Results. No spatial genetic differentiation was identified in either catshark species, while phylogeographic structure of lineages was identified in both skates, with $R$. miraletus more structured than $R$. clavata. However, such structuring of skate lineages was not consistent with the separation 
between Western and Eastern Mediterranean. Sudden demographic expansions occurred synchronously during the upper Pleistocene (40,000-60,000 years ago) in both skates and G. melastomus, likely related to optimal environmental conditions. In contrast, S. caniculaexperienced a slow and constant increase in population size over the last 350,000 years.

Discussion. The comparative analysis of phylogeographic and historical demographic patterns for the Mediterranean populations of these elasmobranchs reveals that historical phylogeographic breaks have not had a large impact on their microevolution. We hypothesize that interactions between environmental and ecological/physiological traits may have been the driving force in the microevolution of these demersal elasmobranch species in the Mediterranean rather than oceanographic barriers. 


\title{
Natural history and molecular evolution of demersal Mediterranean sharks and skates inferred by comparative phylogeographic and demographic analyses
}

\author{
Alice Ferrari ${ }^{1}$, Fausto Tinti $^{1}$, Victoria Bertucci Maresca ${ }^{1,2}$, Alessandro Velonà ${ }^{1}$, Rita Cannas ${ }^{3}$, loannis \\ Thasitis ${ }^{4}$, Filipe Oliveira Costa ${ }^{5}$, Maria Cristina Follesa ${ }^{3}$, Daniel Golani ${ }^{6}$, Farid Hemida ${ }^{7}$, Sarah J Helyar ${ }^{8}$, \\ Cecilia Mancusi ${ }^{9}$, Antonello Mulas ${ }^{3}$, Fabrizio Serena ${ }^{10}$, Letizia Sion ${ }^{11}$, Marco Stagioni ${ }^{1}$, Alessia Cariani $^{1}$ \\ ${ }^{1}$ Department of Biological, Geological \& Environmental Sciences (BiGeA), University of Bologna, \\ Bologna, Italy \\ ${ }^{2}$ Department of Life Sciences, University of Trieste, Trieste, Italy \\ ${ }^{3}$ Department of Life Sciences and Environment, University of Cagliari, Cagliari, Italy \\ ${ }^{4}$ Department of Fisheries and Marine Research, Ministry of Agriculture, Natural Resources and \\ Environment, Nicosia, Cyprus \\ ${ }^{5}$ Centre of Molecular and Environmental Biology (CBMA), University of Minho, Braga, Portugal \\ ${ }^{6}$ Department of Evolution, Systematics and Ecology, The Hebrew University of Jerusalem, Jerusalem, \\ Israel \\ ${ }^{7}$ Ecole Nationale Supérieure des Sciences de la Mer et de Aménagement du Littoral, Algiers, Algeria \\ ${ }^{8}$ School of Biological Sciences, Institute for Global Food Security, Queen's University Belfast, \\ Belfast, United Kingdom \\ ${ }^{9}$ Regional Agency for Environmental Protection-Toscana (ARPAT), Livorno, Italy \\ ${ }^{10}$ Institute Coastal Marine Environment, Italian National Research Council (CNR -IAMC), Mazara del \\ Vallo, Italy \\ ${ }^{11}$ Department of Biology, University of Bari, Bari, Italy \\ Corresponding Author: \\ Fausto Tinti ${ }^{1}$ \\ Laboratory of Genetics \& Genomics of Marine Resources and Environment (GenoDREAM) \\ via S. Alberto 163, Ravenna, 48123, Italy \\ Email address: fausto.tinti@unibo.it
}




\section{ABSTRACT}

Background. The unique and complex paleoclimatic and paleogeographic events which affected the Mediterranean Sea since late Miocene deeply influenced the distribution and evolution of marine organisms and shaped their genetic structure. Following the Messinian salinity crisis and the sea-level fluctuations during the Pleistocene, several Mediterranean marine species developed deep genetic differentiation, and some underwent rapid radiation. Here, we consider two of the most prioritized groups for conservation in the light of their evolutionary history: sharks and rays (elasmobranchs). This paper deals with a comparative multispecies analysis of phylogeographic structure and historical demography in two pairs of sympatric, phylogenetically- and ecologicallyrelated elasmobranchs, two scyliorhinid catsharks (Galeus melastomus, Scyliorhinus canicula) and two rajid skates (Raja clavata, Raja miraletus). Sampling and experimental analyses were designed to primarily test if the Sicilian Channel can be considered as effective eco-physiological barrier for Mediterranean demersal sympatric elasmobranchs.

Methods. The phylogeography and the historical demography of target species were inferred by analysing the nucleotide variation of three mitochondrial DNA markers (i.e. partial sequence of COI, NADH2 and CR) obtained from a total of 248 individuals sampled in the Western and Eastern Mediterranean Sea as well as in the adjacent northeastern Atlantic Ocean. Phylogeographic analysis was performed by haplotype networking and testing spatial genetic differentiation of samples (i.e. analysis of molecular variance and of principal components). Demographic history of Mediterranean populations was reconstructed using mismatch distribution and Bayesian Skyline Plot analyses.

Results. No spatial genetic differentiation was identified in either catshark species, while phylogeographic structure of lineages was identified in both skates, with $R$. miraletus more structured than $R$. clavata. However, such structuring of skate lineages was not consistent with the separation between Western and Eastern Mediterranean. Sudden demographic expansions occurred synchronously during the upper Pleistocene (40,000-60,000 years ago) in both skates and G. melastomus, likely related to optimal environmental conditions. In contrast, S. canicula experienced a slow and constant increase in population size over the last 350,000 years. 
Discussion. The comparative analysis of phylogeographic and historical demographic patterns for the Mediterranean populations of these elasmobranchs reveals that historical phylogeographic breaks have not had a large impact on their microevolution. We hypothesize that interactions between environmental and ecological/physiological traits may have been the driving force in the microevolution of these demersal elasmobranch species in the Mediterranean rather than oceanographic barriers. 


\section{INTRODUCTION}

2 The Mediterranean Sea has been universally recognised as a cradle of biodiversity (Cuttelod 3 et al., 2009; Coll et al., 2010; Lejeusne et al., 2010; Mouillot et al., 2011). This characteristic of

4 the Mediterranean is due to its origin in the unique and complex paleoclimatic and paleogeographic 5 histories of the ancient Paratethys (Rögl, 1999) and still relies on the unusual salinity and water 6 circulation conditions, driven by topography and local climatic regimes (Robinson et al., 2001). 7 After the almost total closure of the Atlantic seaway, the basin experienced a nearly complete 8 desiccation (the Messinian Salinity Crisis, $\sim 5.33$ MYA) and about 40 warm interglacial-cold 9 glacial cycles during the Pleistocene (from 2.5 to 0.01 MYA), which caused sea-level oscillations and sea-water temperature changes (Waelbroek et al., 2002). These events have deeply influenced the distribution and evolution of marine organisms and shaped their genetic structure (Nikula \& Väinölä, 2003; Boudouresque 2004; Duran, Pascual \& Turon, 2004; Wörheide, Solé-Cava \& Hooper, 2005; Pérez-Losada et al., 2007).

The majority of genetic studies on Mediterranean fishes have focussed on teleosts (Magoulas et al., 2006; Rolland et al., 2007), whilst there have been far fewer studies conducted on elasmobranchs (Chevolot el al., 2006; Griffiths et al., 2010; Iglésias, Toulhoat \& Sellos, 2010, Pasolini et al., 2011). Considering their uniqueness in terms of evolutionary history, Mediterranean elasmobranchs (89 species; FAO, 2018a; FAO, 2018b) should be high priority for conservation plans to protect against overfishing, by-catch, habitat loss and fragmentation (Serena, 2005; Cavanagh \& Gibson, 2007; Serena, Mancusi \& Barone, 2010; Froese \& Pauly, 2017; Stein et al., 2018). Hence, for conservation and management purposes, genetic surveys have recently been carried out to disentangle the genetic structure, phylogeography and gene flow among several Mediterranean populations in an important fishery resources, including Scyliorhinus canicula (Barbieri et al., 2014; Gubili et al., 2014; Kousteni et al., 2015) and the endemic skates Raja polystigma (Frodella et al., 2016) and $R$. asterias (Cariani et al., 2017).

By analysing mtDNA variation in sympatric species and reconstructing the impact of the past events and processes leading to contemporary biota, comparative phylogeography can contribute to inferences of common evolutionary and demographic processes (Avise et al., 1987; Avise, 2000; Arbogast \& Kenagy, 2001). In particular, phylogeography helps to unravel the distribution of ancestral lineages based on haplotypes shared by contemporary individuals under a 
32 species may help to identify unifying/similar mechanisms triggering the evolution of particular 33 marine species (Arbogast \& Kenagy, 2001). Hence, the coupling of a phylogeographic approach 34 with historical demography may empower the testing of micro-evolutionary hypotheses 35 (Drummond et al., 2005; Campos et al., 2010; Ho \& Shapiro, 2011), the identification of factors 36 driving past population dynamics (Finlay et al., 2007; Patarnello, Volckaert \& Castilho, 2007; Atkinson, Gray \& Drummond, 2008; Stiller et al., 2010) and range expansions (Fahey et al., 2012).

Within the Mediterranean Sea, the transition area of the Sicilian Channel has been considered a major barrier to the dispersal of marine species between the Western and Eastern sub-basins, even if it is not the unique barrier assessed therein (Bianchi \& Morri, 2000; Bianchi, 2007; Patarnello et al., 2007; Coll et al., 2010). However, the role of the Sicilian Channel as a partial barrier to marine species dispersal rather than a transition/genetic admixture area is still under scrutiny (Pascual et al., 2017). This transition area affects the species richness of elasmobranchs, which are higher in the western part of the Mediterranean than in the eastern part (Coll et al., 2010). However, even if tested with different experimental designs and molecular markers, the barrier role of the Sicilian Channel transition area in the geographical structuring of mtDNA variation seems to be comparatively low. The small-spotted catshark $S$. canicula exhibited strong genetic structure as revealed by significant mtDNA and microsatellite-based fixation indexes, regardless a consistent strong phylogeographic break between western and eastern populations. Indeed, haplotypes from the two sub-basins were phylogenetically intermingled and weakly divergent in the haplotype median-joining networks (Barbieri et al., 2014; Gubili et al., 2014; Kousteni et al., 2015). In R. polystigma, Frodella et al. (2016) found a lack of genetic structure and a very weak phylogeographic break between the western Mediterranean and the Adriatic population, representing the only sample from the eastern sub-basin.

The processes shaping the genetic architecture in marine species are affected by historical abundance and dispersal. Changes in population size and geographical distribution can be reflected by changes in the genetic diversity and differentiation (Grant \& Waples, 2000; Patarnello et al., 2007). Although temporal estimates based on molecular-clock calibration are constrained by molecular and physiological parameters (due to differences in evolutionary rates across taxa, and the effects of differences in generation time, metabolic rate and body size (Martin \& Palumbi, 1993; Gillooly et al., 2005; Grant et al., 2012), haplotype diversity and divergence still demonstrate 
63 2000; Patarnello et al., 2007). Improved models and analytical tools for the inference of 64 demographic changes over time based on genetic data have been shown to be highly informative 65 for elucidating past population dynamics (Kuhner, 2009). It has been demonstrated that the 66 elasmobranch mtDNA substitution rate is approximately $10 \%$ slower than that of teleosts, and that 67 the combined use of multiple sequence markers can improve the resolution of phylogeographic 68 and demographic analyses (Frodella et al., 2016).

69 This paper deals with a comparative multispecies analysis of phylogeographic structure and 70 historical demography in two pairs of sympatric, phylogenetically- and ecologically- related 71 elasmobranchs to test for common natural histories and environmental/climatic factors (i.e. 72 phylogeographic breaks), which may potentially have driven their microevolution. Nucleotide 73 variation in the target species, namely the rajid skates Raja clavata L. (thornback ray) and $R$. 74 miraletus L. (brown skate), and the scyliorhinid catsharks Galeus melastomus (Rafinesque, 1810; 75 blackmouth catshark) and Scyliorhinus canicula L. (small-spotted catshark), was analysed at three 76 mitochondrial gene fragments which have been proven polymorphic at the population level 77 (Barbieri et al., 2014; Gubili et al., 2014; Kousteni et al., 2015; Frodella et al., 2016; Cariani et al., 78 2017; Ramírez-Amaro et al., 2018). Sampling and experimental analyses were designed to 79 primarily test if the Sicilian Channel has been acted as an eco-physiological barrier for 80 Mediterranean demersal sympatric elasmobranchs. Moreover, the inclusion of several population 81 samples from two geographical areas within each sub-basin will allow the opportunity to detect 82 additional phylogeographic breaks in the region. 
84 MATERIALS AND METHODS

85 Sampling

86

87

were collected during international research cruises (e.g. MEDITS Bertrand et al., 2002) or by

88 contracted commercial fishermen between 2001 and 2010 from 17 sites, located in the northeastern Atlantic and throughout the Mediterranean Sea (Figure 1, Table 1, Table S1). The sampling design was established according to the main zoogeographical boundary dividing Western (WMED) and Eastern (EMED) Mediterranean sub-basins as proposed by Pérès \& Picard (1964), Giaccone \& Sortino (1974) and Bianchi \& Morri (2000; 2007). Within each sub-basin, sampling locations were grouped into two geographical areas (Table 1, Table S1). In this study, satisfactory sample sizes remained a major challenge, especially for the species that are inadequately represented in commercial catches (i.e. R. miraletus) due to catchability and/or selectivity characteristics of associated fishing methods (i.e. trawl system vs. "rapido" trawl). Individuals were specifically assigned using the available identification guidelines and keys (Serena, 2005; Serena, Mancusi \& Barone, 2010).

Sampling of sharks and skates was carried out fully respecting the fishing dispositions of the

Regulation of the European Parliament and of the Council on certain provisions for fishing in the GFCM (General Fisheries Commission for the Mediterranean) Agreement area and amending Council Regulation (EC) No 1967/2006 concerning management measures for the sustainable exploitation of fishery resources in the Mediterranean Sea, adopted by the Council on 20th October $2011(2011 / \mathrm{C} 345 \mathrm{E} / 01)$.

\section{Molecular methods}

After on-board collection, individual tissues were preserved in $96 \%$ ethanol at $-20^{\circ} \mathrm{C}$ until laboratory analyses. Total genomic DNA (gDNA) was extracted using the CTAB protocol (Doyle \& Doyle, 1987). Three mitochondrial gene fragments were amplified and sequenced: the cytochrome oxidase c subunit I (COI), the nicotinamide dehydrogenase subunit 2 (NADH2) and

111 the control region (CR). Skate-specific primer pairs for the amplification of the mitochondrial 112 NADH2 gene were designed. This was carried out using homologous complete mitochondrial 113 DNA (mtDNA) sequences of Okamejei kenojei (AY525783.1; NC_007173.1; Kim et al., 2005) 114 and Amblyraja radiata (NC_000893.1; Rasmussen \& Arnason, 1999). Available sequences were 
115 retrieved from GenBank and aligned using ClustalW algorithm implemented in MEGA7 (Kumar,

116 Steche \& Tamura, 2016). A consensus sequence was then used as input for primer design. Primer

117 pairs were chosen using the online tool PRIMER3 v.4 (Untergasser et al., 2012) according to the

118 minimum probability of primers to produce dimers or hairpins. Primers were tested on a Biometra

119 Gradient Thermocycler to define the most suitable melting temperatures (Tm ranging from $50^{\circ} \mathrm{C}$

120 to $60^{\circ} \mathrm{C}$ ). The complete list of primers used to amplify mtDNA gene fragments in each species is

121 reported in Table S2. PCR reactions were performed in $50 \mu \mathrm{L}$ reactions using the Taq DNA

122 polymerase PCR kit (Invitrogen). The thermal profile consisted of an initial denaturation step at

$12394^{\circ} \mathrm{C}$ for $5 \mathrm{~min}, 35$ cycles of denaturation at $94^{\circ} \mathrm{C}$ for $30 \mathrm{~s}$, annealing at Ta (as detailed in Table

$124 \mathrm{~S} 2$ ) for $30 \mathrm{~s}$, extension at $72^{\circ} \mathrm{C}$ for $30 \mathrm{~s}$, and a final elongation step at $72^{\circ} \mathrm{C}$ for $10 \mathrm{~min}$. Total PCR

125 products were purified and sequenced at Macrogen Europe ${ }^{\circledR}$.

126

\section{Data analyses}

128 For each species, COI, NADH2 and CR partial sequences were aligned with ClustalW 129 algorithm implemented in MEGA and concatenated to generate a combined dataset for subsequent 130 analyses.

131 The software DnaSP v.6 (Rozas et al., 2017) was used to identify the number of haplotypes,

132 the number of polymorphic and parsimony informative sites for each mitochondrial marker and

133 for the combined dataset. Haplotype and nucleotide diversity ( \pm standard deviations) were 134 computed as measures of genetic diversity for each geographical area and sub-basin, and 135 significant differences between the two sub-basins were tested for with Ruxton's (2006) test.

136 Species-specific haplotype networks were created using the TCS method as implemented in 137 PopART v.1.7 (Leigh \& Bryant, 2015).

138 The Analysis of Molecular Variance (AMOVA) was performed with Arlequin v.3.5 139 (Excoffier \& Lischer, 2010) grouping the Mediterranean samples on the basis of a priori 140 hierarchical geographical structure on three levels: between sub-basins; between geographical 141 areas, within sub-basin; within geographical areas. The statistical significance of the resulting $\Phi$

142 values was estimated by comparing the observed distribution with a null distribution generated by 14310,000 permutations, in which individuals were redistributed randomly into samples.

144 The population structure was also assessed by a Principal Component Analysis (PCA) 145 performed with the software Past v.2.03 (Hammer, Harper \& Ryan, 2001) on a pairwise genetic 
146 distance matrix calculated between individuals using the best-fitting models selected with MEGA.

147 The $95 \%$ ellipses were plotted to obtain the probabilistic distribution space of each geographical 148 population sample.

149 The demographic histories of the Mediterranean shark and skate populations were 150 reconstructed using three different approaches. We firstly performed the Tajima's $D$, Fu's $F_{\mathrm{S}}$ and 151 Ramos-Onsis \& Rozas's $R_{2}$ neutrality tests (Tajima, 1989; Fu, 1997; Ramos-Onsis \& Rozas, 2002)

152 as implemented in DnaSP. Under a population expansion model, significant negative values of $D$ 153 and $F_{\mathrm{S}}$ and significant positive values of $R_{2}$ were expected; the statistical significance was tested 154 using 10,000 permutations. In the second approach, we estimated the "mismatch distribution" 155 (Rogers \& Harpending, 1992), i.e. the frequency distribution of the pairwise differences among 156 sequences. The mismatch distribution was estimated under the assumption of a sudden expansion 157 model as implemented in Arlequin. To determine the fit of our experimental data to the model 158 distribution, the sum of squared deviations (SSD) between observed and expected mismatch 159 distributions and the raggedness index ( $r g$ ) were used as test statistics with 1,000 bootstrap 160 replicates. Lastly, we reconstructed the historical demography using the coalescent-based 161 Bayesian Skyline Plot approach (BSP; Kingman, 1982a, 1982b; Drummond et al., 2005; Ho \& 162 Shapiro, 2011), implemented in the software package BEAST v.1.8.4 (Drummond \& Rambaut, 163 2012), under the best-fit models previously selected, a strict molecular clock and a mutation rate 164 of $0.005 /$ million years (Chevolot et al., 2006). This mutation rate was obtained using a substitution 165 rate estimated in a wider taxonomic framework using the times of divergence between Rajinae and 166 Amblyrajinae (at $31 \mathrm{Myr}$ ) and within the main groups within Rajinae determined by Valsecchi et 167 al. (2005). However, because mutation rates may vary across elasmobranch lineages and across 168 genes within the mtDNA genome, applying this mutation rate to catsharks and to other mtDNA 169 gene fragments should be considered with caution. To ensure convergence of the posterior 170 distributions, we performed two independent Markov Chain Monte Carlo runs of 50,000,000 171 generations sampled every 5,000 generations, with the first $10 \%$ of the sampled points discarded 172 as burn-in. Runs were subsequently combined in LogCombiner (included in the BEAST package).

173 The quality of the run was assessed by effective sample size (ESS) $>200$ for each parameter using 174 Tracer v.1.5 (Rambaut \& Drummond, 2007). This software was also used to generate the skyline 175 plots. 


\section{RESULTS}

178 The sequence variation of the separate and combined datasets in each species is reported in

179 Table 2. As expected, the non-coding CR haplotypes (81) outnumbered those of the coding genes

180 (COI: 38; NADH2: 43). The percentage of variable sites and of parsimony informative sites for 181 the combined dataset ranged from $1.5 \%$ to $2.5 \%$ and from $0.7 \%$ to $1.8 \%$, respectively.

182 Estimates of haplotype diversity $(h)$ were high in all samples, with the exception of the skate 183 samples from Balearic, Ligurian and Tyrrhenian Seas (Table 3). Mean values of $h$ and nucleotide 184 diversity $(\pi)$ were significantly higher in the EMED than in the WMED samples in all species, except for S. canicula (Ruxton test, $\mathrm{P}<0.001$; Table 3).

186 The thornback ray $R$. clavata showed a star-like network with the most common haplotype 187 shared by all Mediterranean samples as well as by the northeastern Atlantic (NEATL) (Figure 2).

188 Slightly differentiated geographical haplotype lineages were detected in EMED (i.e. one formed 189 by Adriatic individuals and one predominated by Levantine individuals) and in WMED. In 190 addition to the most common haplotype, two low-frequency haplotypes were shared between 191 Algerian coasts and the Adriatic and Levantine Sea. A divergent NEATL lineage formed by two 192 unique haplotypes was also detected.

193 In contrast, the brown skate $R$. miraletus, exhibited a stronger phylogeographic structure 194 across the Mediterranean samples than $R$. clavata, indicated by the presence of three 195 Mediterranean and one northeastern Atlantic/Western Mediterranean haplotype clusters (Figure 196 3). Another lineage included haplotypes shared by Portuguese (NEATL) and Algerian individuals. 197 This haplogroup slightly differed from a second haplogroup formed by the most frequent Mediterranean haplotype shared by Balearic-Tyrrhenian Sea and Adriatic Sea individuals and three single-individual haplotypes. Additionally, two more divergent lineages were constituted by Adriatic-Levantine and Levantine brown skates.

201 The haplotype networks of both catsharks showed a complete lack of phylogeographic 202 signal, without any geographical distinction between Mediterranean and NEATL samples, or 203 between WMED and EMED samples (Figure 4 and Figure 5).

204 The PCA results were consistent with those of the haplotype network analysis (Figure 6), 205 revealing a lack of spatial structure in G. melastomus and S. canicula, the partial genetic 206 differentiation of NEATL and Adriatic samples of $R$. clavata and the separation of $R$. miraletus 207 samples into three genetic groups. 
The AMOVA (Table 4) did not reveal significant divergence between WMED and EMED 209 in any species, even though $R$. miraletus and G. melastomus showed remarkable percentages of 210 molecular variation between sub-basins (28.70\% and 7.01\%, respectively). Conversely, high 211 molecular variation was detected between geographical areas within sub-basins in $R$. clavata, $R$. 212 miraletus and $S$. canicula, revealing a genetic structure independent from their grouping in 213 Western and Eastern Mediterranean sub-basins.

214 The estimated Tajima's $D$, Fu's $F_{S}$ and Ramos-Onsins \& Rozas's $R_{2}$ indexes were largely 215 consistent within each species (Table 5). Significant indexes strongly suggested a sudden 216 demographic expansion of the Mediterranean $R$. clavata, while no significant values were obtained 217 for the populations of other species with the exception of Fu's $F_{S}$ index in S. canicula.

218 Both catsharks showed a unimodal mismatch distribution, R. clavata showed a skewed 219 unimodal mismatch distribution, and the mismatch distribution of $R$. miraletus was bimodal 220 (Figure 7). The statistical analysis of the species-specific mismatch distributions (Table 5, SSD 221 and $r g$ indexes) revealed that the observed distributions were not statistically different from those 222 expected under a sudden expansion model in all species, even if the SSD and $r g$ values of $R$. 223 miraletus were higher than those estimated for the other species (Table 5). In R. clavata, R. 224 miraletus and G. melastomus the BSP analysis consistently indicated that sudden demographic 225 expansions occurred approximately 40,000-60,000 years ago, while S. canicula exhibited a 226 constant, slow demographic expansion over the last 350,000 years (Figure 8). 
228

229

230

231

232

233

234

235

236

237

238

239

240

241

242

243

244

245

246

247

248

249

250

251

252

253

254

255

256

257

258

\section{DISCUSSION}

This study was characterized by a high sampling effort in terms of geographical coverage. Despite the variability and some restrictions of the sample size, we were able to sample 17 locations across the Mediterranean Sea as well as including samples from the northeastern Atlantic. One limitation of this work is the lack of samples from the Alboran and Aegean Seas, two areas that are known to be conservation and biodiversity hot spots for elasmobranchs (Coll et al., 2010) and in which some of the target species have shown independent historical population dynamics (e.g. the demographic decline shown by S. canicula in the Aegean Sea; Kousteni et al., 2015).

The multispecies comparative analysis did not reveal phylogeographical structuring on a latitudinal scale. However, distinct groups were found within sub-basins in both the brown skate and the small-spotted catshark, although not for the tested hypothesis of western-eastern historical separation. These results refute the hypothesis of an effective role of the Siculo-Tunisian transition area as a barrier in shaping natural history and microevolution of these demersal sharks and skates. However, it should be noted that physical and/or physiological barriers (e.g. the Strait of Gibraltar, the Almeria-Oran oceanographic front) did not always differentiate populations of marine phylogenetically- and ecologically-related taxa with similar differentiation patterns (e.g. the discordant differentiation genetic patterns of the Atlantic-Mediterranean seabream species Diplodus puntazzo and D. sargus described in Bargelloni et al. (2005). In addition, the SiculoTunisian transition area can also affect the contemporary population connectivity and gene flow, leading to strong genetic divergence among western and eastern populations as shown for the small-spotted catshark S. canicula (Gubili et al., 2014; Kousteni et al., 2015).

Our results indicate a lack of deep phylogeographic structure in both scyliorhinid sharks: the blackmouth catshark G. melastomus, a species widely distributed in the outer continental shelves and upper slopes (55-1200 m depth), and the small-spotted catshark S. canicula, which inhabits the shallow waters of continental shelves (prevalent in 10-100 m depth) and the uppermost slopes (200-400 m depth). For the blackmouth catshark, our findings are consistent with the results of a recent small-scale study, which showed an absence of population structure and high connectivity in the Western Mediterranean Sea (Ramírez-Amaro et al., 2018). In contrast, the lack of phylogeographic structure we observed in the Mediterranean for the small-spotted catshark could not be considered to be entirely consistent with the results of previous studies. Gubili et al. (2014) 
259 combined mitochondrial (CR) and nuclear (SSRs) markers and detected a strong differentiation 260 within the Mediterranean Sea, where regardless of which molecular marker was used. 261 Accordingly, the population from Eastern Mediterranean was significantly divergent from those 262 of the other geographical areas (Gubili et al., 2014). Similarly, Kousteni et al. (2015) identified a 263 deep genetic structure between the Western and the Eastern sub-basins and a weak differentiation 264 of the Aegean population. In contrast, samples from the Levantine Sea shared haplotypes with 265 both Western and Eastern sub-basins. Barbieri et al. (2014) analysed the geographical variation of 266 S. canicula and observed several region-unique COI haplotypes corresponding to the Western267 Eastern Mediterranean Sea and the Adriatic Sea, suggesting that the Sicilian Channel could not be 268 considered a barrier to gene flow for this species. However, the haplotype networks built in all 269 these studies did not detect western and eastern Mediterranean mtDNA clades, though all 270 haplotype-frequency-based estimates indicated strong and significant contemporary 271 differentiation between the sub-basins and, within each of them, among populations from different 272 seas (Barbieri et al., 2014; Gubili et al., 2014; Kousteni et al., 2015). Such discrepancies could be 273 due to incomplete lineage sorting likely related to the recent origin of the Mediterranean 274 populations. In order to infer a reasonable phylogeographic scenario, even more Mediterranean 275 areas need to be included, such as the Alboran and Aegean Seas, as well as samples from the southernmost coasts (e.g. Gulf of Sirte). Nevertheless, the phylogeographic pattern we detected in S. canicula widely overlaps with those identified in previous works.

Raja miraletus showed a considerably different phylogeographic pattern compared to those of both catsharks and the congeneric species, $R$. clavata. In contrast, the thornback ray (R. clavata) did not display well-identified geographical haplotype clusters. Both species showed any specific mtDNA lineage in the Adriatic Sea and this appears different with respect to the $R$. polystigma, that exhibited a weakly divergent but fixed COI haplotype (Frodella et al., 2016). The present findings for the thornback ray agree with those of Chevolot et al. (2006), in which a relic, unique cytb haplotype was identified for samples from Corsica, the Adriatic and Black Seas. Our findings also coincide with the CR results of Pasolini et al. (2011), in which no geographical clades were identified within the Mediterranean. Due to a higher adult dispersal potential as suggested by a

287 larger body size, $R$. clavata may be able to inhabit deeper waters and may thus be able to colonize 288 different geographical areas compared to coastal, shallow-water species, such as the small-sized 289 congeneric R. miraletus (Sion et al., 2004; Serena, 2005; Serena, Mancusi \& Barone, 2010). 
Although mtDNA variance was not significantly different between Western and Eastern

291 Mediterranean populations in any of the elasmobranch species considered, we detected significant 292 differences in the levels of genetic diversity in three out of four taxa. In R. clavata, R. miraletus 293 and G. melastomus, the mtDNA diversity of the Western Mediterranean samples was significantly 294 lower than the Eastern ones, while the Balearic, Ligurian and Tyrrhenian samples revealed the 295 lowest haplotype and nucleotide diversity, especially in $R$. miraletus. In general, low values of 296 haplotype and nucleotide diversity may indicate evolutionary and ecological processes (i.e. 297 bottleneck or recent founder events). Thus, further analyses based on high-resolution markers, 298 should be conducted in order to explore these scenarios.

299 Although the Sicilian Channel has not been a significant barrier in the historical process of 300 differentiation in these demersal elasmobranchs, it may currently be acting as an effective barrier 301 limiting dispersal and gene flow between populations inhabiting the Mediterranean sub-basins 302 (Gubili et al., 2014; Kousteni et al., 2015). Similar patterns of genetic differentiation were also 303 recently detected in $R$. miraletus (Ferrari 2017) and in R. asterias (Cariani et al., 2017). The role 304 of the Siculo-Tunisian area as a physical/physiological barrier to population connectivity has also 305 been demonstrated for several teleost fish (Kotoulas, Bonhomme \& Borsa, 1995; Mattiangeli et 306 al., 2003; Suzuki et al., 2004; Garoia et al., 2007; Debes, Zanchos \& Hanel, 2008). Differential 307 physiological effects of seawater temperature and salinity discontinuities in the area and the 308 differences between the Western and Eastern Mediterranean (Hopkins, 1985; Coll et al., 2010) are 309 likely to affect the level of early-life stage dispersal of bony fish. However, the magnitude of this 310 oceanographic break is more evident in benthic teleosts (Kotoulas, Bonhomme \& Borsa, 1995;

311 Suzuki et al., 2004; Garoia et al., 2007) and in species inhabiting the northern part of Mediterranean 312 (Debes, Zanchos \& Hanel, 2008).

313 Complementary to microevolutionary processes, environmental and ecological factors could 314 also have driven the diversification of Mediterranean elasmobranchs and may account for their 315 discordant phylogeographic patterns. The fundamental role of ecological features in the 316 demographic histories of demersal elasmobranchs is further emphasised by the mismatch 317 distribution and the BSP analyses conducted here. Despite the application of a mutation rate (used 318 as prior in the BSP analysis) that has been estimated solely from rajid lineages and with different 319 mtDNA gene fragments (cytb and 16S rDNA; Valsecchi et al., 2005; Chevolot et al., 2006), past 320 demographic expansions were detected in all investigated species. In particular, synchronous 
321 sudden expansions were experienced by the thornback ray, brown skate, and the blackmouth

322 catshark approximately 40,000-60,000 years ago. In contrast, the small-spotted catshark exhibited

323 a constant demographic growth in the last 350,000 years. Recently, Kousteni et al. (2015) utilised

324 mitochondrial COI and estimated a weak decline in population size in the Aegean Sea that has

325 been related to the restricted habitat availability during the Pleistocene. In contrast, the glacial 326 period potentially caused a slight increase of the population size in the Ionian Sea (Kousteni et

327 al., 2015). Middle and Late Pleistocene cycles of glacial and interglacial periods, with related

328 paleoclimatic and sea-level changes, seem to have influenced demographic histories of the 329 northeastern Atlantic and Mediterranean marine fauna as indicated by species- or population330 specific demographic expansions between 1.1 to 0.05 MYA (e.g. algae, Hoarau et al., 2007; 331 invertebrates, Luttikhuizen et al., 2003, Stamatis et al., 2004, Calderòn et al., 2008; vertebrates, 332 Gysels et al., 2004, Aboim et al., 2005, Alvarado-Bremer et al., 2005, Charrier et al., 2006, 333 Chevolot et al., 2006, Larmuseau et al., 2009). Among Mediterranean fish populations, more 334 recent expansions (from 350,000 to 50,000 years ago) have affected those of the Atlantic Bluefin 335 tuna, Thunnus thynnus (Alvarado-Bremer et al., 2005) and the sand goby, Pomatoschistus minutus

336 (Larmuseau et al., 2009). While remains difficult to identify factors that could have driven the 337 demographic expansion of these benthic marine taxa in the Mediterranean, overlapping 338 demographic expansions may have been caused by similar environmental shifts such as benthic 339 habitat changes at the beginning of the last glacial period (Würm, from 70,000 to 15,000 years 340 ago; Graham, Dayton \& Erlandson, 2003, Liu et al., 2011). However, within this period our data 341 indicate that the Last Glacial Maximum (from 26,500 to 20,000 years ago) did not strongly affect

342 the demographic histories of marine species and populations inhabiting the northeastern Atlantic 343 and Mediterranean ecosystems by blurring the previous Middle and Late Pleistocene demographic 344 expansions (Chevolot et al., 2006; Hoarau et al., 2007; Larmuseau et al., 2009).

\section{CONCLUSIONS}

347 The comparative analysis of phylogeographic and historical demographic patterns for the 348 Mediterranean populations of these elasmobranchs reveals that historical phylogeographic breaks 349 have not had a large impact on their differentiation. The minor role of the Sicilian Channel 350 transition area has potentially prevented the complete sorting of haplotype lineages between the 351 Western and Eastern Mediterranean, though sub-basin-specific lineages have been observed 
352 among the species. The demographic histories of the four target species are very similar, indicating 353 a recent origin of these populations with the exception of the brown skate, suggesting that may

354 have experienced a different demographic history likely related to past changes in the benthic 355 habitat conditions. Overall, historical barriers to dispersal appear to play a negligible role in the 356 ecology, distribution and genetic diversity of elasmobranch populations in the Mediterranean 357 compared to biotic and abiotic factors.

358

359

\section{ACKNOWLEDGEMENTS}

360 We thank the two anonymous reviewers and Dr. Panagiotis Kasapidis for the criticisms and 361 suggestions that helped to improve the manuscript. We also thank all contributors to this research.

362 In particular, we are grateful to the MEDITS partners for their sampling effort.

363

364

\section{REFERENCES}

Aboim MA, Menezes GM, Schlitt T, Rogers AD. 2005. Genetic structure and history of 366 populations of the deepsea fish Helicolenus dactylopterus (Delaroche, 1809) inferred from mtDNA sequence analysis. Molecular Ecology 14(5):1343-1354. DOI:10.1111/j.1365294X.2005.02518.x.

369

Alvarado Bremer JR, Vinas J, Ely B, Pla C. 2005. Comparative phylogeography of Atlantic bluefin tuna and swordfish: the combined effects of vicariance, secondary contact, introgression, and population expansion on the regional phylogenies of two highly migratory pelagic fishes. Molecular Phylogenetics and Evolution 36(1):169-187. DOI:10.1016/j.ympev.2004.12.011.

Arbogast BS, Kenagy GJ. 2001. Comparative phylogeography as an integrative approach to historical biogeography. Journal of Biogeography 28(7):819-825. DOI:10.1046/j.13652699.2001.00594.x.

Atkinson QD, Gray RD, Drummond AJ. 2008. mtDNA variation predicts population size in humans and reveals a major Southern Asian chapter in human prehistory. Molecular Biology and Evolution 25(2):468-474. DOI:10.1093/molbev/msm277.

Avise JC. 2000. Phylogeography: the history and formation of species. Cambridge: Harvard University Press. 
382

383

384

385

386

387

388

Avise JC, Arnold J, Ball RM, Bermingham E, Lamb T, Neigel JE, Reeb CA, Saunders NC. 1987. Intraspecific phylogeography: the mitochondrial DNA bridge between population genetics and systematics. Annual Review of Ecology, Evolution, and Systematics 18(1):489522.

Bargelloni L, Alarcon JA, Alvarez MC, Penzo E, Magoulas A, Palma J, Patarnello T. 2005. The Atlantic-Mediterranean transition: discordant genetic patterns in two seabream species, Diplodus puntazzo (Cetti) and Diplodus sargus (L.). Molecular Phylogenetics and Evolution 36(3):523-535. DOI:10.1016/j.ympev.2005.04.017.

Barbieri M, Maltagliati F, Roldán MI, Castelli A. 2014. Molecular contribution to stock identifcation in the small-spotted catshark, Scyliorhinus canicula (Chondrichthyes, Scyliorhinidae). Fishery Resources 154:1-16. DOI:10.1016/j.fishres.2014.01.021.

Becker RA, Wilks AR, Brownrigg R, Minka TP, Deckmyn A. 2016. maps: Draw Geographical Maps. R package version 3.1.0.

Bertrand JA, Gil de Sola L, Papaconstantinou C, Relini G, Souplet A. 2002. The general specifications of the MEDITS surveys. Scientia Marina 66: 9-17. DOI:10.3989/scimar.2002.66s29.

Bianchi CN. 2007. Biodiversity issues for the forthcoming tropical Mediterranean Sea. Hydrobiologia 580(1):7-21. DOI:10.1007/s10750-006-0469-5.

Bianchi CN, Morri C. 2000. Marine Biodiversity of the Mediterranean Sea: situation, problems and prospects for future research. Marine Pollution Bulletin 40(5):367-376. DOI:10.1016/S0025-326X(00)00027-8.

Boudouresque CF. 2004. Marine biodiversity in the Mediterranean: status of species, populations and communities. Travaux scientifiques du Parc national de Port-Cros 20:97-146.

Caldèron I, Giribet G, Turon X. 2008. Two markers and one history: phylogeography of the edible common sea urchin Paracentrotus lividus in the Lusitanian region. Marine Biology 154(1):137-151. DOI:10.1007/s00227-008-0908-0.

Campos PF, Willerslev E, Sher A, Orlando L, Axelsson E, Tikhonov A, Aaris-Sørensen K, Greenwood AD, Kahlke RD, Kosintsev P, Krakhmalnaya T, Kuznetsova T, Lemey P, MacPhee R, Norris CA, Shepherd K, Suchard MA, Zazula GD, Shapiro B, Gilbert MTP. 2010. Ancient DNA analyses exclude humans as the driving force behind late Pleistocene musk ox (Ovibos moschatus) population dynamics. Proceedings of the National 
413

414

415

416

417

418

419

420

421

422

423

424

425

426

427

428

429

430

431

432

433

434

435

436

437

438

439

440

441

Academy of Sciences of the United States of America 107(12):5675-5680. DOI:10.1073/pnas.0907189107.

Cariani A, Messinetti S, Ferrari A, Arculeo M, Bonello JJ, Bonnici L, Cannas R, Carbonara P, Cau A, Charilaou C, El Ouamari N, Fiorentino F, Follesa MC, Garofalo G, Golani D, Guarniero I, Hanner R, Hemida F, Kada O, Lo Brutto S, Mancusi C, Morey G, Schembri PJ, Serena F, Sion L, Stagioni M, Tursi A, Vrgoc N, Steinke D, Tinti F. 2017. Improving the Conservation of Mediterranean Chondrichthyans: The ELASMOMED DNA Barcode Reference Library. PLoS One 12:e0170244. DOI:10.1371/journal.pone.0170244.

Castilho R, Freitas M, Silva G, Fernandez-Carvalho J, Coelho R. 2007. Morphological and mitochondrial DNA divergence validates blackmouth, Galeus melastomus, and Atlantic sawtail catsharks, Galeus atlanticus, as separate species. Journal of Fish Biology 70(sc):346-358. DOI:10.1111/j.1095-8649.2007.01455.x.

Cavanagh RD, Gibson C. 2007. Overview of the conservation status of cartilaginous fishes (Chondroicthyans) in the Mediterranean Sea Gland, Switzerland and Malaga, Spain. No.3 IUCN.

Charrier G, Chenel T, Durand JD, Girard M, Quiniou L, Laroche J. 2006. Discrepancies in phylogeographical patterns of two European anglerfishes (Lophius budegassa and Lophius piscatorius). Molecular Phylogenetics and Evolution 38(3):742-754. DOI:10.1016/j.ympev.2005.08.002.

Chevolot M, Hoarau G, Rijnsdorp AD, Stam WT, Olsen JL. 2006. Phylogeography and population structure of thornback rays (Raja clavata L., Rajidae). Molecular Ecology 15(12):3693-3705. DOI:10.1111/j.1365-294X.2006.03043.x.

Coll M, Piroddi C, Steenbeek J, Kaschner K, Lasram FBR. 2010. The Biodiversity of the Mediterranean Sea: Estimates, Patterns, and Threats. PLoS One 5(8):e11842. DOI:10.1371/journal.pone.0011842.

Costa FO, Landi M, Martins R, Costa MH, Costa ME, Carneiro M, Alves MJ, Steinke D, Carvalho GR. 2012. A ranking system for reference libraries of DNA barcodes: application to marine fish species from Portugal. PLoS One 7(4):e35858. DOI:10.1371/journal.pone.0035858 
442 Cuttelod A, García N, Malak DA, Temple H J, Katariya V. 2009. The Mediterranean: a

443

444

445

446

447

448

449

450

451

452

453

454

455

456

457

458

459

460

461

462

463

464

465

466

467

468

469

470

471 biodiversity hotspot under threat. Wildlife in a Changing World-an analysis of the 2008 IUCN Red List of Threatened Species. 89.

Debes PV, Zachos FE, Hanel R. 2008. Mitochondrial phylogeography of the European sprat (Sprattus sprattus L., Clupeidae) reveals isolated climatically vulnerable populations in the Mediterranean Sea and range expansion in the northeast Atlantic. Molecular Ecology 17(17):3873-3888. DOI:10.1111/j.1365-294X.2008.03872.x.

Doyle JJ, Doyle JL. 1987. A rapid DNA isolation procedure for small amounts of fresh leaf tissue. Phytochemistry Bulletin 19:11-15.

Drummond AJ, Rambaut A, Shapiro B, Pybus OG. 2005. Bayesian coalescent inference of past population dynamics from molecular sequences. Molecular Biology and Evolution 22(5):1185-1192. DOI:10.1093/molbev/msi103.

Drummond AJ, Suchard MA, Xie D \& Rambaut A. 2012. Bayesian phylogenetics with BEAUti and the BEAST 1.7 Molecular Biology and Evolution 29(8):1969-1973. DOI:10.1093/molbev/mss075.

Duran S, Pascual M, Turon X. 2004. Low levels of genetic variation in mtDNA sequences over the western Mediterranean and Atlantic range of the sponge Crambe crambe (Poecilosclerida). Marine Biology 144(1):31-35. DOI:10.1007/s00227-003-1178-5.

Excoffier L, Lischer HE. 2010. Arlequin suite ver3.5: a new series of programs to perform population genetics analyses under Linux and Windows. Molecular Ecology Resources 10(3):564-567 DOI 10.1111/j.1755-0998.2010.02847.x.

Fahey AL, Ricklefs RE, Latta SC, DeWoody JA. 2012. Comparative Historical Demography of Migratory and Nonmigratory Birds from the Caribbean Island of Hispaniola. Evolutionary Biology 39(3):400-414. DOI:10.1007/s11692-012-9164-9.

FAO, 2018a. Species Photographic Plates. Mediterranean Sharks, by Monica Barone, Fabrizio Serena and Mark Dimech. Rome, Italy. Available at http://www.fao.org/3/i6911en/I6911EN.pdf

FAO, 2018b. Species Photographic Plates. Mediterranean skates, rays and chimaeras, by Monica Barone, Fabrizio Serena and Mark Dimech. Rome, Italy. Available at http://www.fao.org/3/i8615en/I8615EN.pdf 
472 Felsenstein J. 2005. Accuracy of coalescent likelihood estimates: do we need more sites, more

473

474

475

476

477

478

479

480

481

482

483

484

485

486

487

488

489

490

491

492

493

494

495

496

497

498

499

500

501

sequences, or more loci? Molecular Biology and Evolution 23(3):691-700. DOI:10.1093/molbev/msj079.

Ferrari A. 2017. Differential gene expression of dorsal pictorial ornaments and pigmentation in skates (Rajidae, Chondrichthyes). PhD Thesis. Alma Mater Studiorum - University of Bologna.

Finlay EK, Gaillard C, Vahidi SM, Mirhoseini SZ, Jianlin H, Qi XB, El-Barody MAA, Baird JF, Healy BC, Bradley DG. 2007. Bayesian inference of population expansions in domestic bovines. Biology Letters 3(4):449-452. DOI:10.1098/rsbl.2007.0146.

Frodella N, Cannas R, Velonà A, Carbonara P, Farrell ED, Fiorentino F, Follesa MC, Garofalo G, Hemida F, Mancusi C, Stagioni M, Ungaro N, Serena F, Tinti F, Cariani A. 2016. Population connectivity and phylogeography of the Mediterranean endemic skate Raja polystigma and evidence of its hybridization with the parapatric sibling $R$. montagui. Marine Ecology Progress Series 554: 99-113. DOI: https://doi.org/10.3354/meps11799.

Froese R, Pauly D. 2017. FishBase. World Wide Web electronic publication. Available at www.fishbase.org (accessed 13 February 2017).

Fu YX. 1997. Statistical tests of neutrality of mutations against population growth, hitchhiking and background selection. Genetics 147(2):915-925.

Garoia F, Guarniero I, Grifoni D, Marzola S, Tinti F. 2007. Comparative analysis of AFLPs and SSRs efficiency in resolving population genetic structure of Mediterranean Solea vulgaris. Molecular Ecology 16(7):1377-1387. DOI:10.1111/j.1365-294X.2007.03247.x.

Giaccone G, Sortino M. 1974. Zonazione della vegetazione marina delle Isole Egadi (Canale di Sicilia). Lav. Istituto Botanico Giardino Colonna Palermo 25:165-183.

Gillooly JF, Allen AP, West GB, Brown JH. 2005. The rate of DNA evolution: effects of body size and temperature on the molecular clock. Proceedings of the National Academy of Sciences of the United States of America 102(1):140-145. DOI:10.1073/pnas.0407735101.

Graham MH, Dayton PK, Erlandson JM. 2003. Ice ages and ecological transitions on temperate coasts. Trends in Ecology and Evolution 18(1):33-40. DOI:10.1016/S0169-5347(02)00006$\mathrm{X}$. 
502 Grant WS, Liu M, Gao T, Yanagimoto T. 2012. Limits of Bayesian skyline plot analysis of

503

504

505

506

507

508

509

510

511

512

513

514

515

516

517

518

519

520

521

522

523

524

525

526

527

528

529

530

531

532 mtDNA sequences to infer historical demographies in Pacific herring (and other species). $\begin{array}{lllll}\text { Molecular Phylogenetics and (1):203-212. } & \text { Evolution }\end{array}$ DOI:10.1016/j.ympev.2012.06.006.

Grant WS, Waples RS. 2000. Spatial and temporal scales of genetic variability in marine and anadromous species: Implications of fisheries oceanography. Pp. 61-93 in P.J. Harrison and T. Parsons (eds.). Fisheries Oceanography: An Integrative Approach to Fisheries Ecology and Management. Blackwell Science, Oxford, UK.

Griffiths AM, Sims DW, Cotterell SP, El Nagar A, Ellis JR, Lynghammar A, McHugh M, Neat FC, Pade NG, Queiroz N, Serra-Pereira, B, Rapp T, Wearmouth VJ, Genner MJ. 2010. Molecular markers reveal spatially segregated cryptic species in a critically endangered fish, the common skate (Dipturus batis). Proceedings of the Royal Society of London B: Biological Sciences rspb20092111. DOI:10.1098/rspb.2009.2111.

Gubili C, Sims DW, Veríssimo A, Domenici P, Ellis J, Grigoriou P, Johnson AF, McHugh M, Neat F, Satta A, Scarcella G, Serra-Pereira B, Soldo A, Genner MJ, Griffiths AM. 2014. A tale of two seas: contrasting patterns of population structure in the small-spotted catshark across Europe. Royal Society open science 1(3):140-175. DOI:10.1098/rsos.140175.

Gysels E, Hellemans B, Pampoulie C, Volckaert FA. 2004. Phylogeography of the common goby, Pomatoschistus microps, with particular emphasis on the colonization of the Mediterranean and the North Sea. Molecular Ecology 13(2):403-417. DOI:10.1046/j.1365294X.2003.02087.x.

Hammer Ø, Harper D, Ryan P. 2001. PAST-PAleontological STatisitics software package for education and data analysis. Palaeontologia Electronica 4.

Hasegawa M, Kishino H, Yano TA. 1985. Dating of the human ape splitting by a molecular clock of mitochondrial-DNA. Journal of Molecular Evolution 22(2):160-174.

Hewitt G. 2000. The genetic legacy of the Quaternary ice ages. Nature 405(6789):907-913. DOI: $10.1038 / 35016000$.

Hoarau G, Coyer JA, Veldsink JH, Stam WT, Olsen JL. 2007. Glacial refugia and recolonization pathways in the brown seaweed Fucus serratus. Molecular Ecology 16(17):3606-3616. DOI:10.1111/j.1365-294X.2007.03408.x. 
533 Hopkins TS. 1985. Physics of the sea. In: Margalef R, ed. Key environments: Western Mediterranean. New York: Pergamon Press, 100-125.

Iglésias SP, Lecointre G, Sellos DY. 2005. Extensive paraphylies within sharks of the order Carcharhiniformes inferred from nuclear and mitochondrial genes. Molecular Phylogenetics and Evolution 34(3):569-583. DOI:10.1016/j.ympev.2004.10.022.

Iglésias SP, Toulhoat L, Sellos DY. 2010. Taxonomic confusion and market mislabelling of threatened skates: important consequences for their conservation status. Aquatic Conservation: Marine and Freshwater Ecosystems 20(3):319-333 DOI:10.1002/aqc.1083.

Kim IC, Jung SO, Lee YM, Lee CJ, Park JK, Lee JS. 2005. The complete mitochondrial genome of the rayfish Raja porosa (Chondrichthyes, Rajidae). DNA Sequence, 16(3):187194.

Kingman JFC. 1982a. The coalescent. Stochastic Processes and their Applications, 13:235-248.

Kingman JFC. 1982b. On the genealogy of large populations. Journal of Applied Probability, 19A:27-43.

Knebelsberger T, Landi M, Neumann H, Kloppmann M, Sell AF, Campbell PD, Laakmann for the identification of the North European shelf fish fauna. Molecular ecology resources, 14(5):1060-1071. 1060-1071. DOI:10.1111/1755-0998.12238.

Kotoulas G, Bonhomme E, Borsa R. 1995. Genetic structure of the common sole Solea vulgaris at different geographic scales. Marine Biology 122(3):361-375.

Kousteni V, Kasapidis P, Kotoulas G, Megalofonou P. 2015. Strong population genetic structure and contrasting demographic histories for the small-spotted catshark (Scyliorhinus canicula) in the Mediterranean Sea. Heredity 114(3):333. DOI:10.1038/hdy.2014.107.

Kumar S, Stecher G, Tamura K. 2016. MEGA7: Molecular Evolutionary Genetics Analysis version 7.0 for bigger datasets. Molecular Biology and Evolution 33(7):1870-1874. DOI:10.1093/molbev/msw054.

Kuhner MK. 2009. Coalescent genealogy samplers: windows into population history. Trends in Ecology \& Evolution. 24(2):86-93. DOI: 10.1016/j.tree.2008.09.007. 
564

565

566

567

568

569

570

571

572

573

574

575

576

577

578

579

580

581

582

583

584

585

586

587

588

589

590

591

592

marine demersal fish in the North-eastern Atlantic. Journal of Biogeography 36(6):11381151. DOI:10.1111/j.1365-2699.2008.02072.x.

Leigh, JW, Bryant D. 2015. PopART: Full-feature software for haplotype network construction. Methods in Ecology and Evolution 6(9):1110-1116. DOI:10.1111/2041-210X.12410

Lejeusne C, Chevaldonné P, Pergent-Martini C, Boudouresque CF, Perez T. 2010. Climate change effects on a miniature ocean: the highly diverse, highly impacted Mediterranean Sea. Trends in Ecology and Evolution 25(4):250-260. DOI:10.1016/j.tree.2009.10.009.

Liu JX, Tatarenkov A, Beacham TD, Grbachev V, Wildes S, Avise JC. 2011. Effects of Pleistocene climatic fluctuations on the phylogeographic and demographic histories of Pacific herring (Clupea pallasii). Molecular Ecology 20(18):3879-3893. DOI:10.1111/j.1365-294X.2011.05213.x.

Luttikhuizen PC, Drent J, van Delden W, Piersma T. 2003. Spatially structured genetic variation in a broadcast spawning bivalve: Quantitative vs. molecular traits. Journal of Evolutionary Biology 16(2):260-272. DOI:10.1046/j.1420-9101.2003.00510.x.

Magoulas A, Castilho R, Caetano S, Marcato S, Patarnello T. 2006. Mitochondrial DNA reveals a mosaic pattern of phylogeographical structure in Atlantic and Mediterranean populations of anchovy (Engraulis encrasicolus). Molecular Phylogenetics and Evolution 39(3):734-746. DOI:10.1016/j.ympev.2006.01.016.

Martin AP, Palumbi SR. 1993. Body size, metabolic rate, generation time, and the molecular clock. Proceedings of the National Academy of Sciences 90 (9):4087-4091. DOI:10.1073/pnas.90.9.4087.

Mattiangeli V, Ryan AW, Galvin P, Mork J, Cross TF. 2003. Eastern and western poor cod (Trisopterus minutus capelanus) populations in the Mediterranean Sea: evidence from allozyme and minisatellite loci. Marine Ecology 24(4):247-258. DOI:10.1046/j.01739565.2003.00795.x.

Mouillot D, Albouy C, Guilhaumon F, Lasram FBR, Coll M, Devictor V, Meynard CN, Pauly D, Tomasini JA, Troussellier M, Velez L, Watson R, Douzery JP, Mouquet B. 2011. Protected and threatened components of fish biodiversity in the Mediterranean Sea. Current Biology 21(12):1044-1050. DOI:10.1016/j.cub.2011.05.005. 
593 Nikula R, Väinölä R. 2003. Phylogeography of Cerastoderma glaucum (Bivalvia: Cardiidae)

594

595

596

597

598

599

600

601

602

603

604

605

606

607

608

609

610

611

612

613

614

615

616

617

618

619

620

621

622

623 across Europe: a major break in the Eastern Mediterranean. Marine Biology 143(2):339350. DOI:10.1007/s00227-003-1088-6.

Pascual M, Rives B, Schunter C, Macpherson E. 2017. Impact of life history traits on gene flow: A multispecies systematic review across oceanographic barriers in the Mediterranean Sea. PloS one 12(5):e0176419. DOI:10.1371/journal.pone.0176419.

Pasolini P, Ragazzini C, Zaccaro Z, Carinai A, Ferrara G, Gonzales EG, Landi M, Milano I, Stagioni M, Guarniero I, Tinti F. 2011. Quaternary geographical sibling speciation and population structuring in the Eastern Atlantic skates (suborder Rajoidea) R. clavata and $R$. straeleni. Marine Biology 158(10):2173-2186. DOI:10.1007/s00227-011-1722-7.

Patarnello T, Volckaert F, Castilho R. 2007. Pillars of Hercules: is the Atlantic-Mediterranean transition a phylogeographical break? Molecular Ecology 16(21):4426-4444. DOI:10.1111/j.1365-294X.2007.03477.x.

Pérès JM, Picard J. 1964. Nouveau manuel de bionomie benthique de la mer Méditerranée. Station Marine d'Endoume.

Pérez-Losada M, Nolte MJ, Crandall KA, Shaw PW. 2007. Testing hypotheses of population structuring in the Northeast Atlantic Ocean and Mediterranean Sea using the common cuttlefish Sepia officinalis. Molecular Ecology 16(13):2667-2679. DOI:10.1111/j.1365294X.2007.03333.x.

Rambaut A, Drummond AJ. 2007. Tracer 1.5. 0. University of Edinburgh, Edinburgh, UK.

Ramírez-Amaro S, Picornell A, Arenas M, Castro JA, Massutí E, Ramon MM, Terrasa B. 2018. Contrasting evolutionary patterns in populations of demersal sharks throughout the western Mediterranean. Marine Biology 165:3. DOI: 10.1007/s00227-017-3254-2.

Ramos-Onsins SE, Rozas J. 2002. Statistical properties of neutrality tests against population growth. Molecular Biology and Evolution 19(12):2092-2100. DOI:10.1093/oxfordjournals.molbev.a004034.

R Core Team. 2016. R: a language and environment for statistical computing. Version 3.4.1 Vienna: R Foundation for Statistical Computing.

Rasmussen AS, Arnason U. 1999. Molecular studies suggest that cartilaginous fishes have a terminal position in the piscine tree. Proceedings of the National Academy of Sciences of the United States of America. 96(5):2177-2182. 
624 Robinson AR, Leslie WG, Theocharis A, Lascaratos A. 2001. Mediterranean Sea circulation. 625 Ocean currents: a derivative of the Encyclopedia of Ocean Sciences: 1689-1705.

626 Rogers AR, Harpending H. 1992. Population growth makes waves in the distribution of pairwise 627 genetic differences. Molecular Biology and Evolution 9(3):552-569. DOI:10.1093/oxfordjournals.molbev.a040727.

Rögl F. 1999. Mediterranean and Paratethys. Facts and hypotheses of an Oligocene to Miocene paleogeography (short overview). Geologica carpathica 50(4):339-349.

Rolland JL, Bonhomme F, Lagardère F, Hassan M, Guinand B. 2007. Population structure of

Rozas J, Ferrer-Mata A, Sánchez-DelBarrio JC, Guirao-Rico S, Librado P, Ramos-Onsins the common sole (Solea solea) in the Northeastern Atlantic and the Mediterranean Sea: revisiting the divide with EPIC markers. Marine Biology 151(1):327-341. DOI:10.1007/s00227-006-0484-0. SE, Sánchez-Gracia A. 2017. DnaSP 6: DNA Sequence Polymorphism Analysis of Large

\section{Datasets.} Molecular Biology and Evolution

34(12):3299-3302. DOI:10.1093/molbev/msx248.

Ruxton GD. 2006. The unequal variance t-test is an underused alternative to Student's t-test and the Mann-Whitney $U$ test. Behavioral Ecology 17(4):688-690. DOI:10.1093/beheco/ark016.

Serena F. 2005. Field identification guide to the sharks and rays of the Mediterranean and Black 652

Schunter C, Carreras-Carbonell J, Macpherson E, Tintoré J, Vidal-Vijande E, Pascual A, Guidetti P, Pascual M. 2011a. Matching genetics with oceanography: directional gene flow in a Mediterranean fish species. Molecular Ecology 20(24):5167-5181. DOI:10.1111/j.1365-294X.2011.05355.X.

Schunter C, Carreras-Carbonell, J, Planes S, Sala E, Ballesteros E, Zabala M, Harmelin JG, Harmeli-Vivien M, Macpherson E, Pascual M. 2011b. Genetic connectivity patterns in an endangered species: The dusky grouper (Epinephelus marginatus). Journal of Experimental Marine Biology and Ecology 401(1-2):126-133. DOI:10.1016/j.jembe.2011.01.021. Sea. FAO Species Identification Guide for Fishery Purposes. FAO, Rome, Italy. 
653 Serena F, Mancusi C, Barone M. 2010. Field Identification guide to the skates (Rajidae) of the

654

655

656

657

658

659

660

661

662

663

664

665

666

667

668

669

670

671

672

673

674

675

676

677

678

679

680

681

682 Mediterranean Sea. Guidelines for data collection and analysis. Biologia Marina Mediterranea 17(s2):204.

Serra-Pereira B, Moura T, Griffiths AM, Serrano Gordo L, Figueiredo I. 2011. Molecular barcoding of skates (Chondrichthyes: Rajidae) from the southern Northeast Atlantic. Zoologica Scripta, 40(1):76-84. DOI: 10.1111/j.1463-6409.2010.00461.x.

Shadwick RE, Farrell PA, Brauner CJ (eds). 2015. Physiology of Elasmobranch Fishes: Structure and Interaction with Environment. Fish Physiology, Academic Press. 34(Part A). DOI:10.1016/B978-0-12-801289-5.00009-2.

Sion L, Bozzano A, D’Onghia G, Capezzuto F, Panza M. 2004. Chondrichthyes species in deep waters of the Mediterranean Sea. Scientia Marina 68(s3):153-162. DOI:10.3989/scimar.2004.68s3153.

Stamatis C, Triantafyllidis A, Moutou KA, Mamuris Z. 2004. Mitochondrial DNA variation in North East Atlantic and Mediterranean populations of Norway lobster, Nephrops norvegicus. Molecular Ecology 13(6):1377-1390. DOI:10.1111/j.1365294X.2004.02165.x.

Stein RW, Mull CG, Kuhn TS, Aschliman NC, Davidson LN, Joy JB, Smith GJ, Dulvy NK, Mooers AO. 2018. Global priorities for conserving the evolutionary history of sharks, rays and chimaeras. Nature ecology \& evolution 2:288-298. DOI:10.1038/s41559-017-0448-4.

Stiller M, Baryshnikov G, Bocherens H, Bocherens H, Grandal d'Anglade A, Hilpert B, Münzel SC, Pinhasi R, Rabeder G, Rosendahl W, Trinkaus E, Hofreiter M, Knapp M. 2010. Withering away-25 000 years of genetic decline preceded cave bear extinction. Molecular Biology and Evolution 27(5):975-978. DOI:10.1093/molbev/msq083.

Stoner DS, Grady JM, Priede KA, Quattro JM. 2003. Amplification primers for the mitochondrial control region and sixth intron of the nuclear-encoded lactate dehydrogenase A gene in elasmobranch fishes. Conservation Genetics 4(6):805-808. DOI:10.1023/B:COGE.0000006122.47004.c2.

Suzuki N, Nishida M, Yoseda K, Ustundag C, Sahin T, Amaoka K. 2004. Phylogeographic relationships within the Mediterranean turbot inferred by mitochondrial DNA haplotype variation. Journal of Fish Biology 65(2):580-585. DOI:10.1111/j.0022-1112.2004.00433.x. 
683 Tajima F. 1989. Statistical method for testing the neutral mutation hypothesis by DNA

684

685

686

687

688

689

690

691

692

693

694

695

696

697

698

699

700

701

702

703 polymorphism. Genetics 123(3):585-595.

Untergasser A, Cutcutache I, Koressaar T, Ye J, Faircloth BC, Remm M, Rozen SG. 2012. Primer3-new capabilities and interfaces. Nucleic acids research, 40(15): e115-e115. DOI:10.1093/nar/gks596.

Valsecchi E, Pasolini P, Bertozzi M, Garoia F, Ungaro N, Vacchi M, Sabelli B, Tinti F. 2005. Rapid Miocene-Pliocene dispersal and evolution of Mediterranean rajid fauna as inferred by mitochondrial gene variation. Journal of Evolutionary Biology 18(2): 436-446. DOI:10.1111/j.1420-9101.2004.00829.x.

Waelbroeck C, Labeyrie L, Michel E, Duplessy JC McManus JF, Lambeck K, Balbon E, Labracherie M. 2002. Sea level and deep water temperature changes derived from benthic foraminifera isotopic records. Quaternary Science Review 21(1-3):295-305. DOI:10.1016/S0277-3791(01)00101-9.

Ward RD, Zemlak TS, Innes BH, Last PR, Hebert PDN. 2005. DNA barcoding Australia's fish species. Philosophical Transaction of the Royal Society B Biological Sciences 360(1462):1847-1857. DOI:10.1098/rstb.2005.1716.

Wickham H. 2010. ggplot2: elegant graphics for data analysis. Journal of Statistical Softwware 35(1):65-88.

Wörheide G, Solé-Cava AM, Hooper JN. 2005. Biodiversity, molecular ecology and phylogeography of marine sponges: patterns, implications and outlooks. Integrative and Comparative Biology 45(2):377-385. DOI:10.1007/s00227-005-0134-y. 


\section{Figure 1 (on next page)}

Sampling locations of the four demersal elasmobranchs in the study.

Numbers of sampling locations refer to Table 1. Sampling locations for each species are colour coded according to four geographical areas as reported in Table 1. North-Eastern Atlantic sampling locations are not represented. The map was created using R v.3.4.1 (R Core Team, 2016; Wickham 2010; Becker, Wilks \& Brownrigg, 2016). 


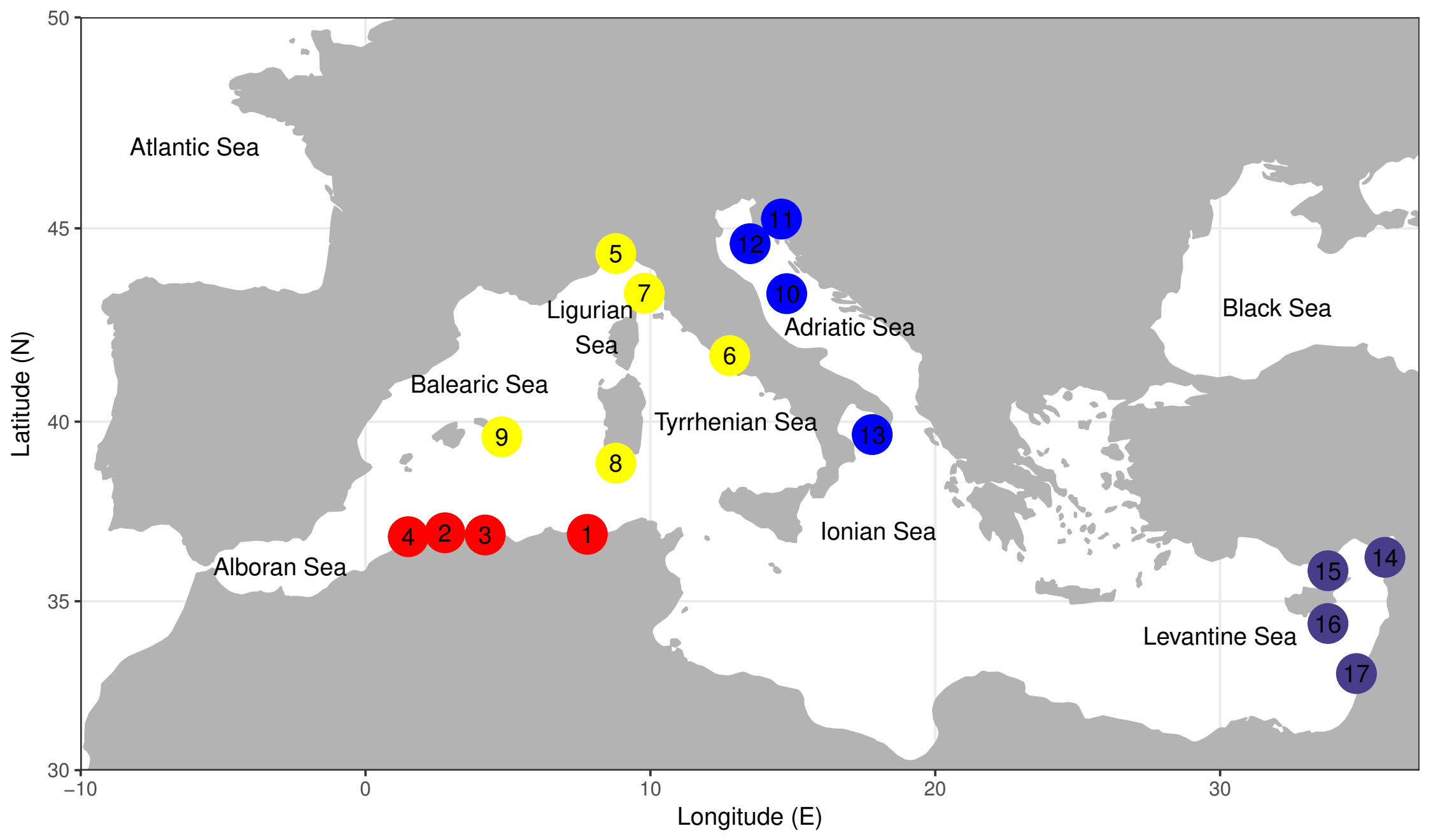


Figure 2

TCS network of combined haplotype of Raja clavata.

Circles are proportional to haplotype frequencies. Colours are consistent with Fig. 1; with the North-eastern Atlantic haplotypes indicated in green. Orthogonal bars between branch nodes indicate substitutions.Black nodes represent unsampled sequences.

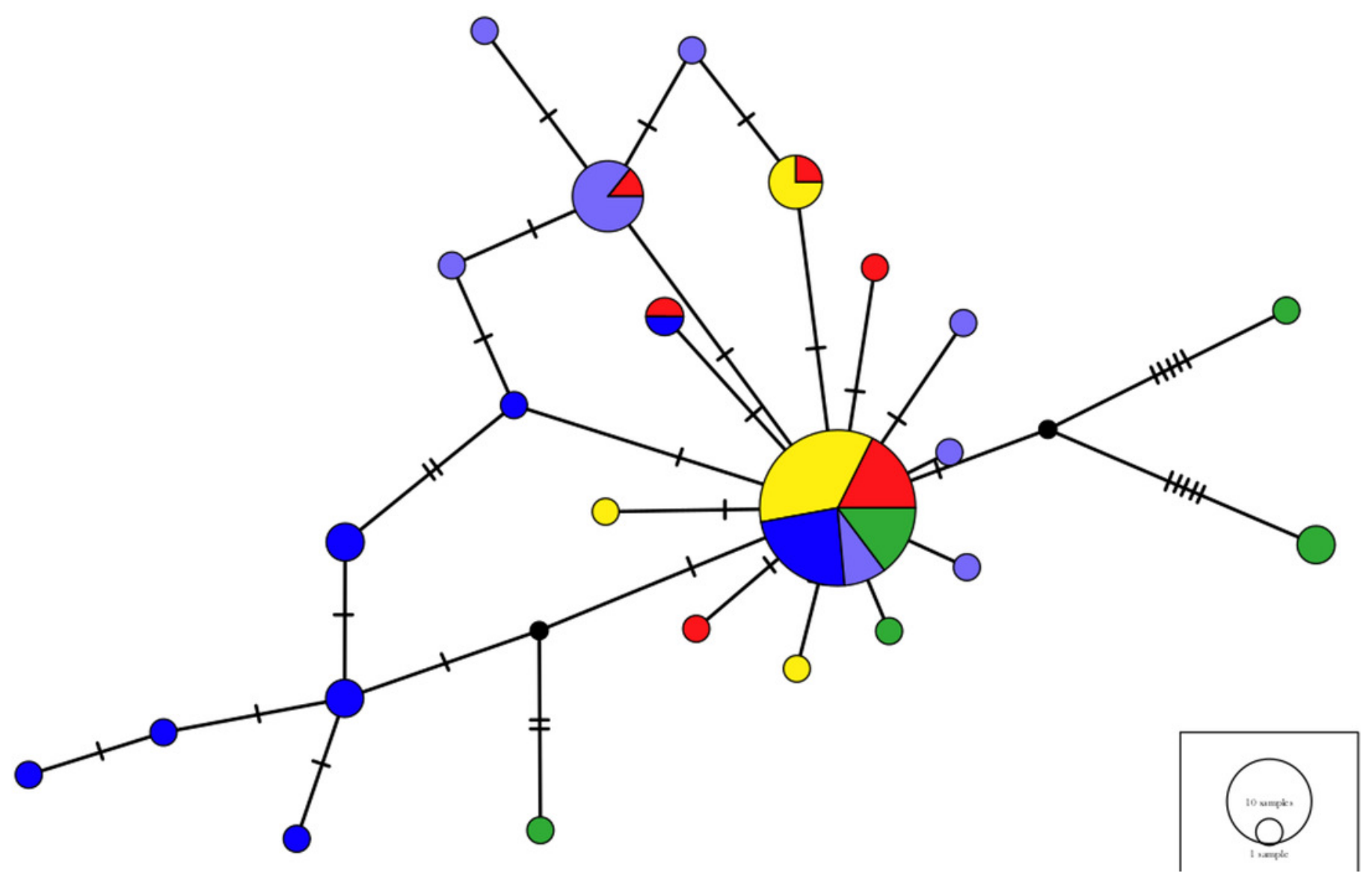


Figure 3

TCS network of combined haplotype of Raja miraletus.

Circles are proportional to haplotype frequencies. Colours are consistent with Fig. 1; with the North-eastern Atlantic haplotypes indicated in green. Orthogonal bars between branch nodes indicate substitutions. Black nodes represent unsampled sequences.

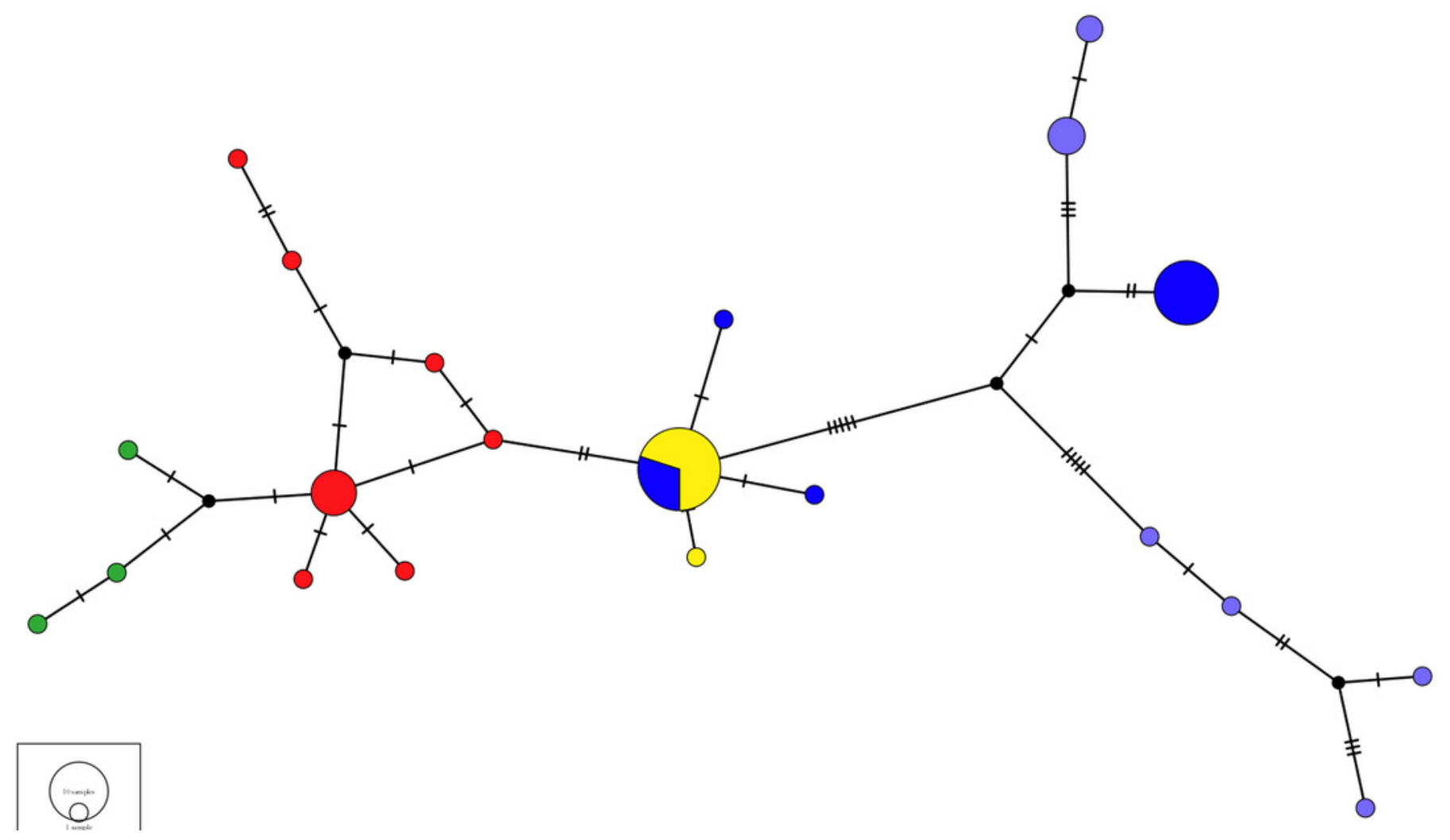


Figure 4

TCS network of combined haplotype of Galeus melastomus.

Circles are proportional to haplotype frequencies. Coloursare consistent with Fig. 1; with the North-eastern Atlantic haplotypes indicated in green. Orthogonal bars between branch nodes indicate substitutions. Black nodes represent unsampled sequences.

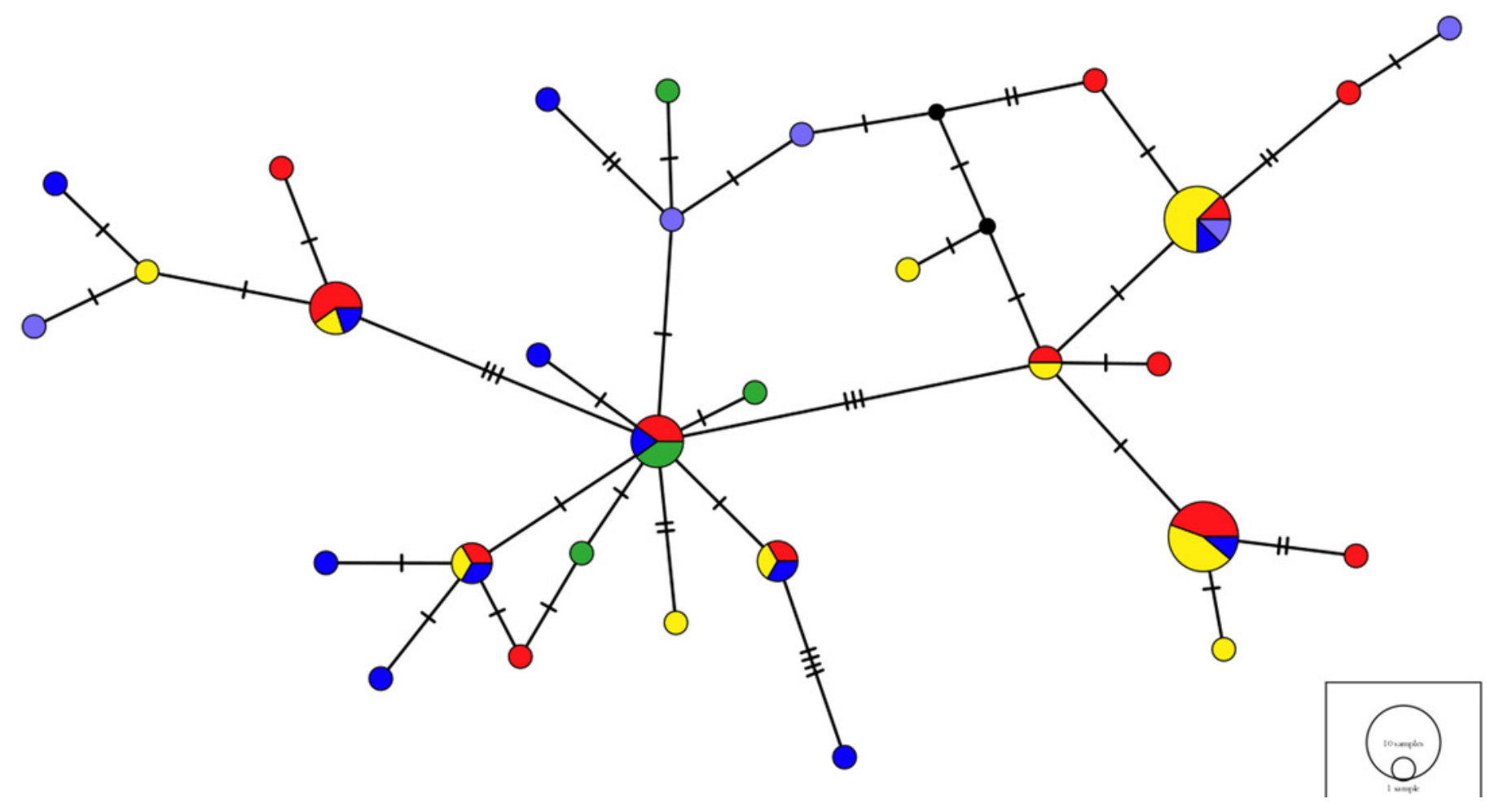


Figure 5

TCS network of combined haplotype of Scyliorhinus canicula.

Circles are proportional to haplotype frequencies. Coloursare consistent with Fig. 1; with the North-eastern Atlantic haplotypes indicated in green. Orthogonal bars between branch nodes indicate substitutions. Black nodes represent unsampled sequences.

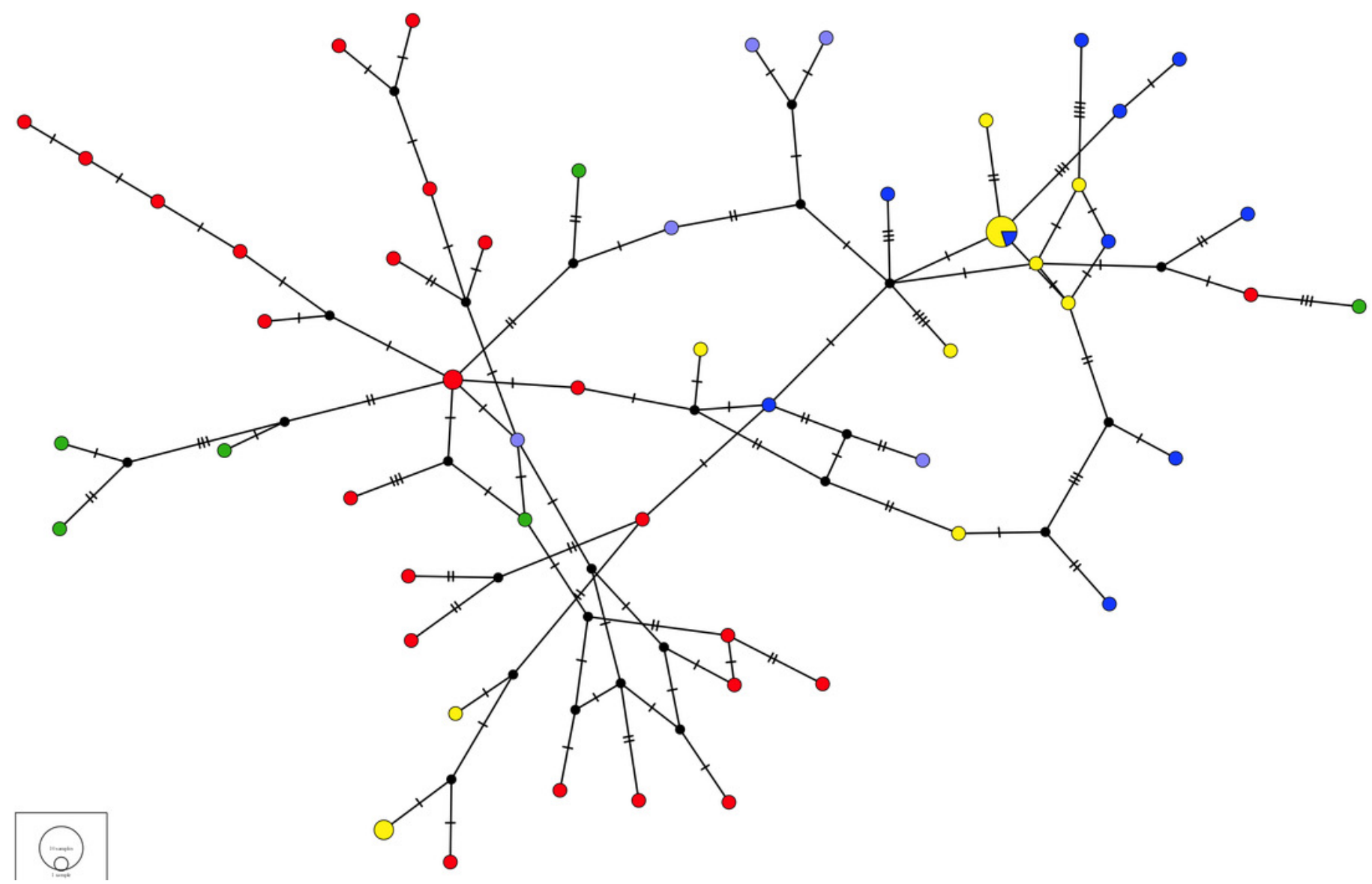


Figure 6

Principal Components Analysis plots.

Plots illustrating the spatial structure of the elasmobranch species considered: (a) Raja clavata, (b) R. miraletus, (c) Galeus melastomusand (d) Scyliorhinus canicula. Colours are consistent with Fig. 1; the North-eastern Atlantic haplotypes are indicated in green. The PCA were carried out on individual sequences, however, only the haplotypes are reported here (dots). For each sample, the $95 \%$ ellipse illustrating the probabilistic distribution space of each geographical sample are shown.
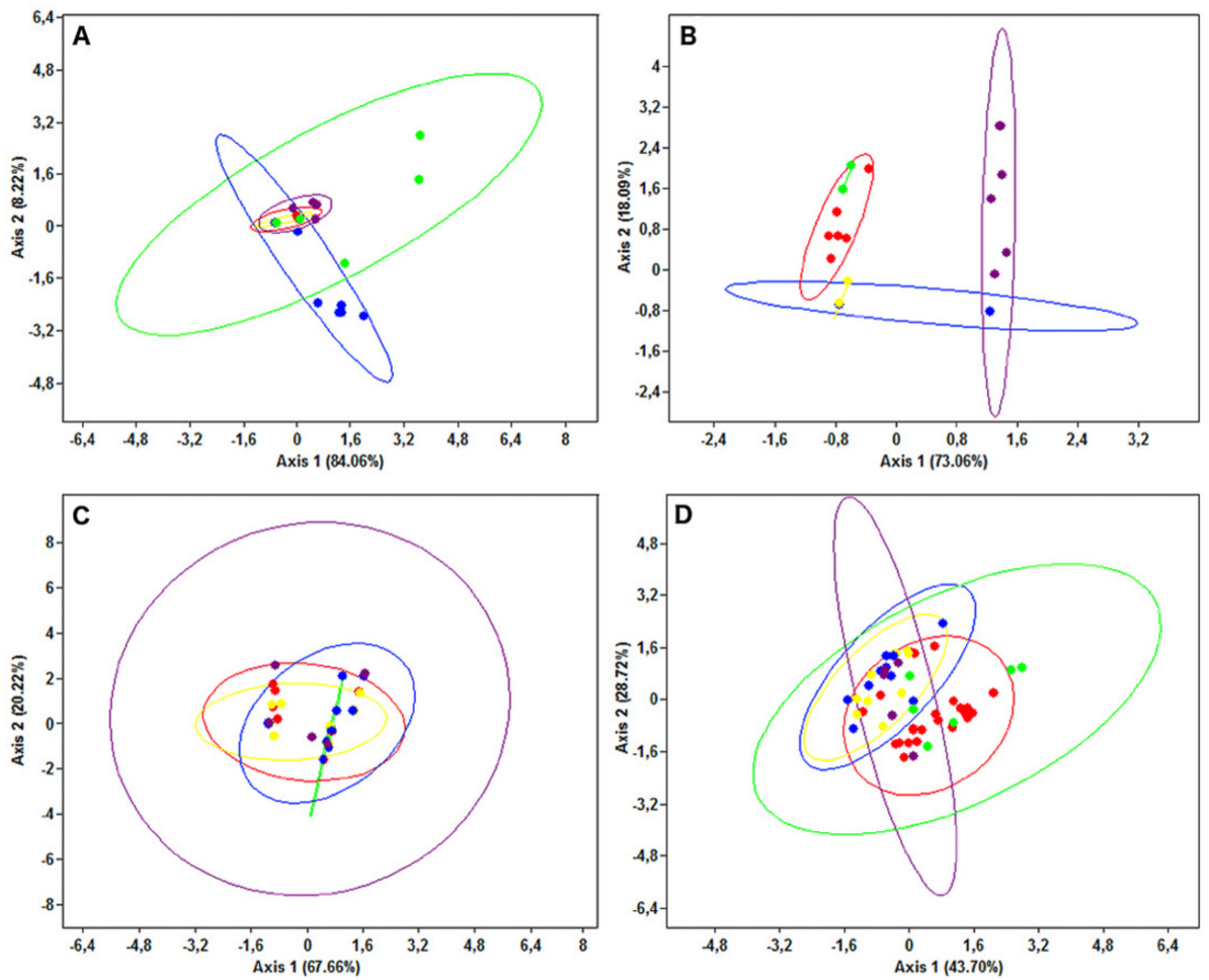


\section{Figure 7}

mtDNA mismatch distribution of the four demersal elasmobranchs in the study.

Observed (bars) and expected (line) mismatch distributions under the sudden expansion model for the Mediterranean populations of the four target species. (A) Raja clavata. (B) Raja miraletus. (C) Galeus melastomus. (D) Scyliorhinus canicula. Results of the statistical analysis of the mismatch distributions are reported in Table 5. 

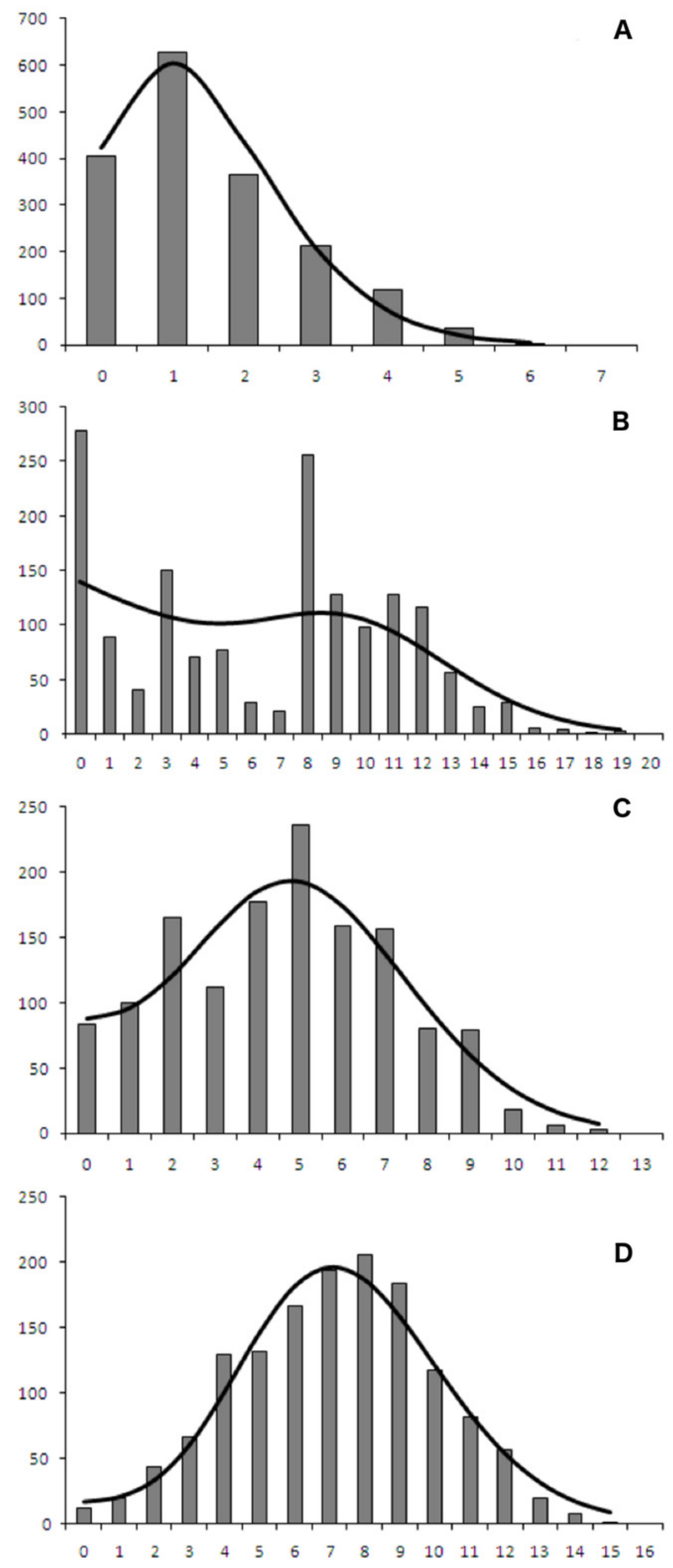

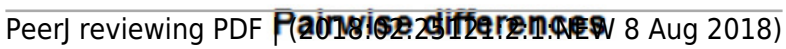




\section{Figure 8}

Bayesian Skyline Plot of the four demersal elasmobranchs in the study.

Plot showing changes in the female effective population sizes (Neft) during time (MYA=million years ago) in the Mediterranean populations of the four target species. (A) Raja clavata. (B) Raja miraletus. (C) Galeus melastomus. (D) Scyliorhinus canicula. Black lines represent the median estimates of female effective population size, while grey lines the upper and the lower $95 \%$ highest posterior density limit. 

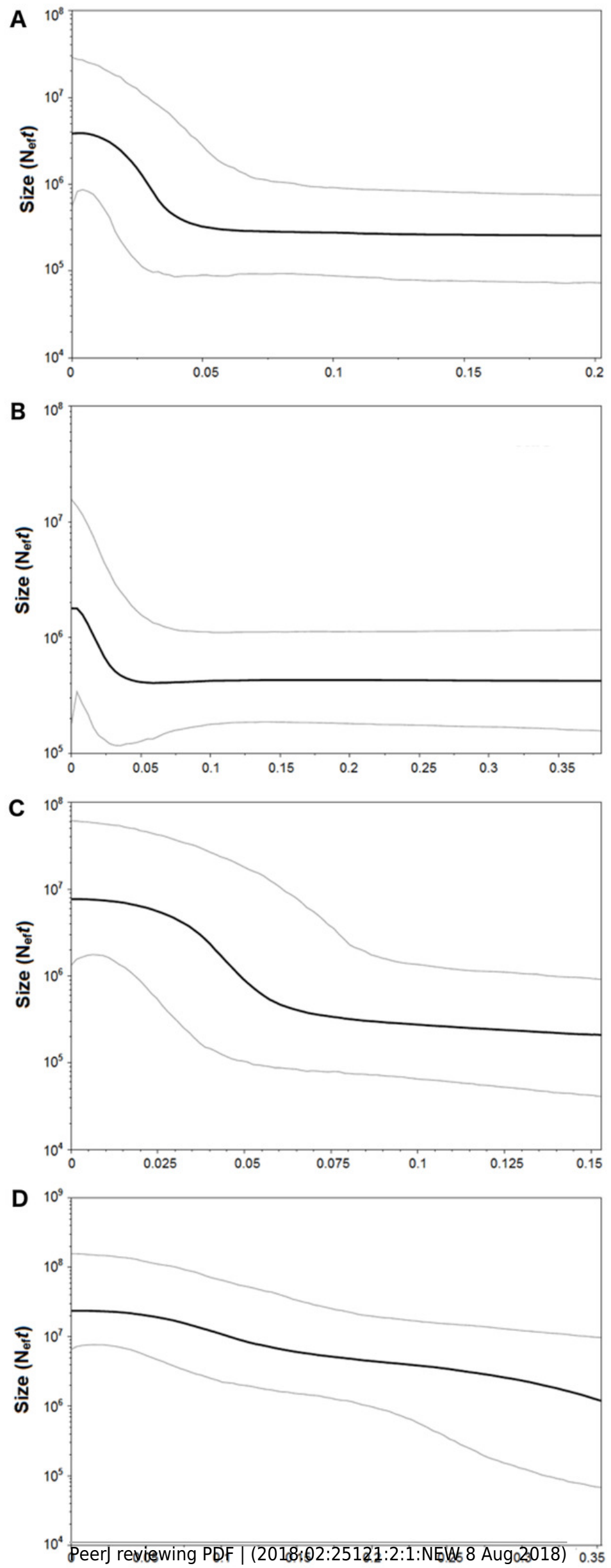

Time (MYA) 


\section{Table $\mathbf{1}$ (on next page)}

Sampling data.

Sampling information, including species, sub-basin and geographical area, sampling location and country, sampling code (see Fig. 1 for location), sample size (N), sampling year and geographical coordinates of the Mediterranean and North-eastern Atlantic samples of the four target elasmobranch species. 


\begin{tabular}{|c|c|c|c|c|c|c|c|}
\hline Species & Sub-basin/Geographical area & $\begin{array}{l}\text { Sampling location, } \\
\text { Country }\end{array}$ & $\begin{array}{l}\text { Sample } \\
\text { code }\end{array}$ & $\mathrm{N}$ & $\begin{array}{l}\text { Sampling } \\
\text { year }\end{array}$ & $\begin{array}{l}\text { Latitude } \\
(\mathrm{N})\end{array}$ & $\begin{array}{l}\text { Longitude } \\
\text { (E) }\end{array}$ \\
\hline \multirow[t]{19}{*}{ Raja clavata } & Western Mediterranean & & & & & & \\
\hline & Algerian coasts & Annaba, Algeria & 1 & 5 & 2001 & $36^{\circ} 54^{\prime} 166$ & $07^{\circ} 47^{\prime} 152$ \\
\hline & & Bouharoun, Algeria & 3 & 6 & 2003 & $36^{\circ} 37^{\prime} 472$ & $02^{\circ} 38^{\prime} 124$ \\
\hline & Ligurian-Tyrrhenian Sea & Genova, Italy & 5 & 3 & 2001 & $44^{\circ} 22^{\prime} 171$ & $08^{\circ} 50^{\prime} 152$ \\
\hline & & Fiumicino, Italy & 6 & 4 & 2001 & $41^{\circ} 45^{\prime} 273$ & $12^{\circ} 07^{\prime} 324$ \\
\hline & & Tuscany, Italy & 7 & 7 & 2002 & $43^{\circ} 22^{\prime} 022$ & $09^{\circ} 55^{\prime} 322$ \\
\hline & & Cagliari, Italy & 8 & 3 & 2009 & $38^{\circ} 52^{\prime} 011$ & $09^{\circ} 20^{\prime} 353$ \\
\hline & Eastern Mediterranean & & & & & & \\
\hline & Adriatic Sea & Marche, Italy & 10 & 5 & 2002 & $43^{\circ} 21^{\prime} 330$ & $14^{\circ} 17^{\prime} 510$ \\
\hline & & Croatian coasts, Croatia & 11 & 3 & 2002 & $45^{\circ} 07^{\prime} 845$ & $14^{\circ} 25^{\prime} 664$ \\
\hline & & Fano, Italy & 12 & 9 & 2006 & $44^{\circ} 31^{\prime} 120$ & $13^{\circ} 00^{\prime} 250$ \\
\hline & Levantine Sea & Antakya, Turkey & 14 & 6 & 2004 & $36^{\circ} 15^{\prime} 203$ & $35^{\circ} 19^{\prime} 114$ \\
\hline & & Iskenderun, Turkey & 15 & 5 & 2004 & $35^{\circ} 52^{\prime} 352$ & $33^{\circ} 33^{\prime} 532$ \\
\hline & & Cyprus coasts, Cyprus & 16 & 4 & 2009 & $34^{\circ} 21^{\prime} 396$ & $33^{\circ} 08^{\prime} 564$ \\
\hline & North-Eastern Atlantic & & & & & & \\
\hline & & Portuguese coasts, Portugal & & 8 & 2005 & $40^{\circ} 85^{\prime} 00$ & $9^{\circ} 20^{\prime} 00$ \\
\hline & & North Cardigan, UK & & 1 & 2006 & $52^{\circ} 42^{\prime} 00$ & $4^{\circ} 32^{\prime} 00$ \\
\hline & & The Wash, UK & & 1 & 2006 & $53^{\circ} 08^{\prime} 00$ & $1^{\circ} 33^{\prime} 00$ \\
\hline & & Total & & 70 & & & \\
\hline \multirow[t]{10}{*}{ Raja miraletus } & Western Mediterranean & & & & & & \\
\hline & Algerian coasts & Cap Djinet, Algeria & 2 & 7 & 2009 & $36^{\circ} 53^{\prime} 012$ & $03^{\circ} 40^{\prime} 201$ \\
\hline & & Annaba, Algeria & 1 & 3 & 2010 & $36^{\circ} 54^{\prime} 166$ & $07^{\circ} 47^{\prime} 152$ \\
\hline & & Tipaza, Algeria & 4 & 2 & 2010 & $36^{\circ} 50^{\prime} 176$ & $03^{\circ} 22^{\prime} 063$ \\
\hline & Balearic-Tyrrhenian Sea & Tuscany, Italy & 7 & 8 & 2010 & $43^{\circ} 22^{\prime} 022$ & $09^{\circ} 55^{\prime} 322$ \\
\hline & & Southern Minorca, Spain & 9 & 7 & 2008 & $39^{\circ} 35^{\prime} 540$ & $04^{\circ} 33^{\prime} 306$ \\
\hline & Eastern Mediterranean & & & & & & \\
\hline & Adriatic Sea & Fano, Italy & 12 & 11 & 2006 & $44^{\circ} 31^{\prime} 120$ & $13^{\circ} 00^{\prime} 250$ \\
\hline & & Croatian coasts, Croatia & 11 & 9 & 2002 & $45^{\circ} 07^{\prime} 845$ & $14^{\circ} 25^{\prime} 664$ \\
\hline & Levantine Sea & Haifa, Israel & 17 & 4 & 2010 & $32^{\circ} 53^{\prime} 567$ & $34^{\circ} 17^{\prime} 550$ \\
\hline
\end{tabular}




\section{North-Eastern Atlantic}

Iskenderun, Turkey $\quad 15 \quad 3 \quad 2004 \quad 35^{\circ} 52^{\prime} 352 \quad 33^{\circ} 33^{\prime} 532$

Cyprus coasts, Cyprus $\quad 16 \quad 3 \quad 2009 \quad 34^{\circ} 21^{\prime} 396 \quad 33^{\circ} 08^{\prime} 564$

\begin{tabular}{|c|c|c|c|c|c|c|}
\hline & North-Eastern Atlantic & & & & & \\
\hline & & $\begin{array}{c}\text { Portuguese coasts, Portugal } \\
\text { Total }\end{array}$ & & $\begin{array}{c}3 \\
60\end{array}$ & 2005 & $38^{\circ} 08^{\prime} 456 \quad 08^{\circ} 49^{\prime} 579$ \\
\hline Galeus melastomus & Western Mediterranean & & & & & \\
\hline & Algerian coasts & Bouharoun, Algeria & 3 & 19 & 2010 & $36^{\circ} 37^{\prime} 47202^{\circ} 38^{\prime} 124$ \\
\hline & Tyrrhenian Sea & Cagliari, Italy & 8 & 17 & 2009 & $38^{\circ} 52^{\prime} 0110^{0} 29^{\circ} 353$ \\
\hline & Eastern Mediterranean & & & & & \\
\hline & Adriatic-Ionian Sea & Fano, Italy & 12 & 8 & 2007 & $44^{\circ} 31^{\prime} 12013^{\circ} 00^{\prime} 250$ \\
\hline & & Ionian Sea, Italy & 13 & 4 & 2008 & $39^{\circ} 39^{\prime} 06517^{\circ} 37^{\prime} 390$ \\
\hline & Levantine Sea & Cyprus coasts, Cyprus & 16 & 5 & 2009 & $34^{\circ} 21^{\prime} 39633^{\circ} 08^{\prime} 564$ \\
\hline & North-Eastern Atlantic & & & & & \\
\hline & & Rockhall Plateau, UK & & 5 & 2010 & - \\
\hline & & Total & & 58 & & \\
\hline
\end{tabular}

Scyliorhinus canicula Western Mediterranean

\begin{tabular}{|c|c|c|c|c|c|}
\hline \multirow[t]{3}{*}{ Algerian coasts } & Bouharoun, Algeria & 3 & 10 & 2010 & $36^{\circ} 37^{\prime} 472 \quad 02^{\circ} 38^{\prime} 124$ \\
\hline & Annaba, Algeria & 1 & 3 & 2010 & $36^{\circ} 54^{\prime} 16607^{\circ} 47^{\prime} 152$ \\
\hline & Tipaza, Algeria & 4 & 12 & 2010 & $36^{\circ} 50^{\prime} 17603^{\circ} 22^{\prime} 063$ \\
\hline yrrhenian Sea & Cagliari, Italy & 8 & 14 & 2009 & $38^{\circ} 52^{\prime} 0110^{\circ} 29^{\circ} 353$ \\
\hline
\end{tabular}

\section{Eastern Mediterranean}

Adriatic Sea

Levantine Sea

Fano, Italy

Cyprus coasts, Cyprus

$12 \quad 10 \quad 2006 \quad 44^{\circ} 31^{\prime} 120 \quad 13^{\circ} 00^{\prime} 250$

North-Eastern Atlantic

Rockhall Plateau, UK Total

$6 \quad 2010$

60 


\section{Table 2 (on next page)}

Sequence information of the separate and combined mtDNA datasets in the four target species.

$S L H=$ haplotype sequence length; $N H=$ number of haplotypes; $V S=$ number of variable sites; $\mathrm{Pi}=$ number of parsimony informative sites. 


\begin{tabular}{|l|l|l|l|l|l|l|l|l|l|l|l|l|l|l|l|l|}
\hline Species & \multicolumn{4}{|c|}{ COI } & \multicolumn{4}{c|}{ NADH2 } & \multicolumn{4}{c|}{ CR } & \multicolumn{3}{c|}{ Combined } \\
\hline & $S L_{H}$ & $N_{H}$ & $V S$ & $P i$ & $S L_{H}$ & $N_{H}$ & $V S$ & $P i$ & $S L_{H}$ & $N_{H}$ & $V S$ & $P i$ & $S L_{H}$ & $N_{H}$ & $V S$ & $P i$ \\
\hline Raja clavata & 579 & 9 & 16 & 7 & 748 & 8 & 8 & 4 & 354 & 9 & 7 & 2 & 1681 & 26 & 31 & 13 \\
\hline Raja miraletus & 601 & 7 & 7 & 6 & 698 & 14 & 15 & 7 & 732 & 12 & 13 & 12 & 2031 & 21 & 35 & 25 \\
\hline Galeus melastomus & 593 & 10 & 9 & 0 & 673 & 9 & 9 & 7 & 667 & 16 & 11 & 11 & 1933 & 30 & 29 & 18 \\
\hline Scyliorhinus canicula & 596 & 12 & 13 & 6 & 749 & 12 & 11 & 10 & 624 & 44 & 25 & 21 & 1969 & 54 & 49 & 37 \\
\hline Total & & $\mathbf{3 8}$ & & & & $\mathbf{4 3}$ & & & & $\mathbf{8 1}$ & & & & $\mathbf{1 3 1}$ & \\
\hline
\end{tabular}




\section{Table 3(on next page)}

Mitochondrial gene polymorphism of the species considered across the sampling areas.

$N=$ Sample size; $N H=$ number of haplotypes; $h=$ haplotype and $p=$ nucleotide diversity $( \pm$ standard deviations, S.D.) for each species in each geographical area and sub-basin; $P=$ probability values of the Ruxton test between WMED vs. EMED hand pvalues; NS=not significant. 


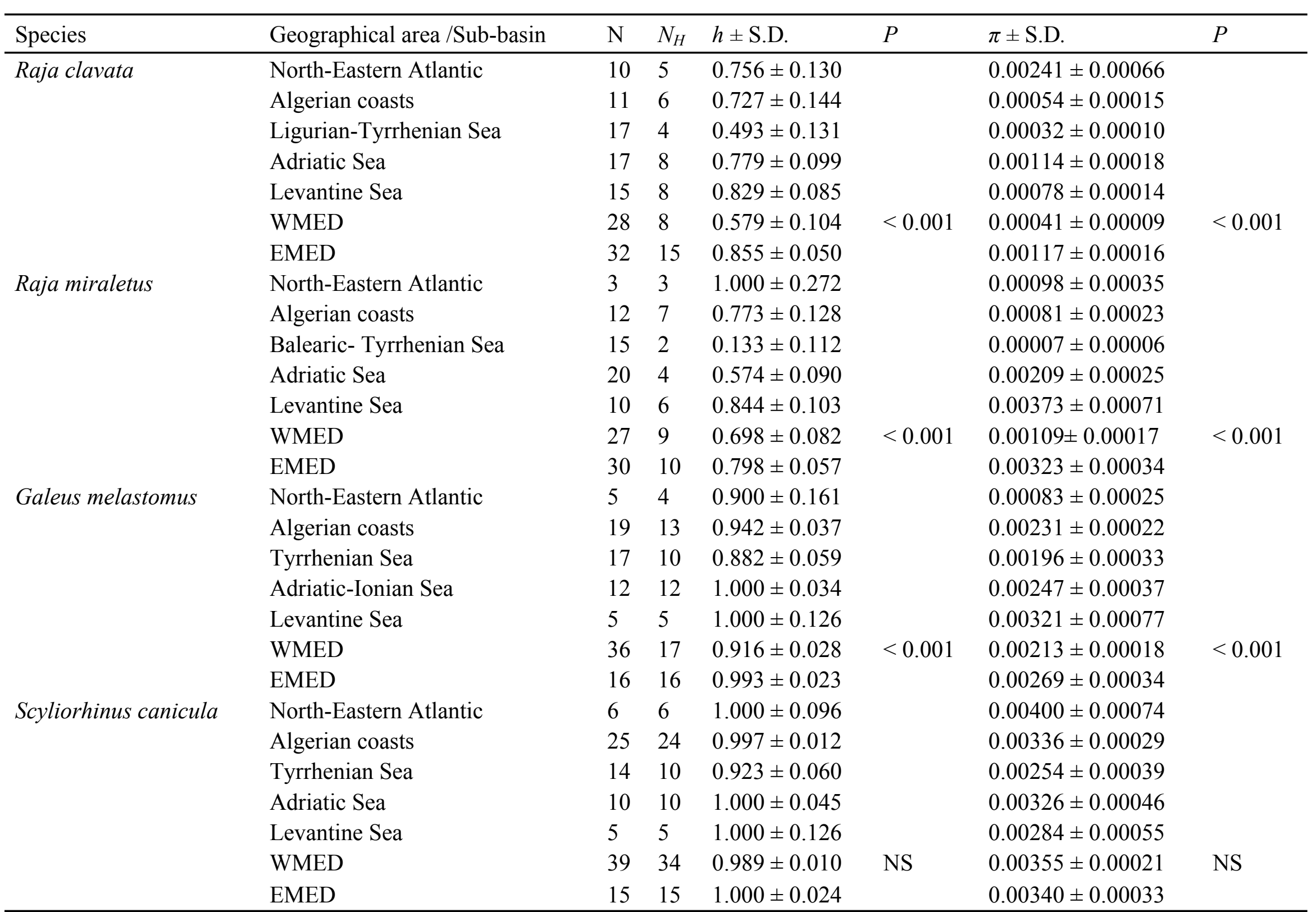




\section{Table 4 (on next page)}

Analysis of Molecular Variance (AMOVA) of mtDNA of the four elasmobranch species.

d.f. $=$ degrees of freedom; $P=$ probability values. 


\begin{tabular}{|c|c|c|c|c|}
\hline Source of variation & d.f. & Sum of squares & $\%$ of variation & $P$ \\
\hline \multicolumn{5}{|l|}{ Raja clavata } \\
\hline Between sub-basins & 1.00 & 3.05 & -1.51 & 1.00 \\
\hline Between areas, within sub-basin & 2.00 & 6.57 & 22.85 & 0.00 \\
\hline Within geographical areas & 56.00 & 35.03 & 78.66 & 0.00 \\
\hline \multicolumn{5}{|l|}{ Raja miraletus } \\
\hline Between sub-basins & 1.00 & 55.94 & 28.70 & 0.35 \\
\hline Between areas, within sub-basin & 2.00 & 39.51 & 32.87 & 0.00 \\
\hline Within geographical areas & 53.00 & 84.42 & 38.44 & 0.00 \\
\hline \multicolumn{5}{|l|}{ Galeus melastomus } \\
\hline Between sub-basins & 1.00 & 6.23 & 7.01 & 0.32 \\
\hline Between areas, within sub-basin & 2.00 & 4.68 & 0.37 & 0.39 \\
\hline Within geographical areas & 48.00 & 109.11 & 92.61 & 0.08 \\
\hline \multicolumn{5}{|l|}{ Scyliorhinus canicula } \\
\hline Between sub-basins & 1.00 & 9.99 & -4.15 & 1.00 \\
\hline Between areas, within sub-basin & 2.00 & 27.49 & 23.18 & 0.00 \\
\hline Within geographical areas & 50.00 & 151.95 & 80.97 & 0.00 \\
\hline
\end{tabular}

1 


\section{Table 5 (on next page)}

Historical demography of the target elasmobranch species.

The Tajima's $D$, Fu's Fs, Ramos-Onsins \& Rozas $R 2$ and mismatch distribution's indices (i.e. sum of squared deviations from the sudden expansion model, SSD, and raggedness index, rg) are reported for each species. The corresponding P-values are given in brackets. 


\begin{tabular}{llllll}
\hline \multirow{2}{*}{ Species } & $D$ & $F_{S}$ & $R_{2}$ & \multicolumn{2}{c}{ Mismatch distribution } \\
\cline { 5 - 6 } & & & & SSD & $r g$ \\
\hline Raja clavata & $-2.260(0.000)$ & $-20.287(0.000)$ & $0.032(0.002)$ & $0.002(0.320)$ & $0.050(0.540)$ \\
Raja miraletus & $-0.393(0.376)$ & $-2.724(0.210)$ & $0.090(0.373)$ & $0.026(0.190)$ & $0.054(0.090)$ \\
Galeus melastomus & $-0.998(0.179)$ & $-18.111(0.999)$ & $0.072(0.165)$ & $0.004(0.680)$ & $0.016(0.660)$ \\
Scyliorhinus canicula & $-1.110(0.117)$ & $-61.416(0.000)$ & $0.073(0.166)$ & $0.001(0.540)$ & $0.007(0.710)$ \\
\hline
\end{tabular}

1 